\title{
Effectiveness of low-carbon development strategies: Evaluation of policy scenarios for the urban transport sector in a Brazilian megacity is
}

\author{
Esther Menezes ${ }^{\mathrm{a}}$, Alexandre Gori Maia ${ }^{\mathrm{b}, *}$, Cristiane Silva de Carvalho $^{\mathrm{c}}$ \\ a Agencia Metropolitana de Campinas, Rua Eng. Candido Gomide, 778, Campinas, SP CEP F6-280, Brazil \\ b Universidade Estadual de Campinas-Instituto de Economia, Rua Pitágoras, 353, Campinas, SP CEP 13083-857, Brazil \\ c Universidade Estadual Paulista-Faculdade de Engenharia, Departamento de Produção, Avenida Doutor Ariberto Pereira da Cunha, Guaratinguetá, SP CEP 12516-410, Brazil
}

\section{A R T I C L E I N F O}

\section{Article history:}

Received 2 March 2015

Received in revised form 3 February 2016

Accepted 17 August 2016

Available online 14 September 2016

\section{JEL classification:}

018

Q54

R41

Keywords:

Urban mobility

Transports

Greenhouse gases

Low-carbon policies

Scenario building

Dynamic simulation

\begin{abstract}
A B S T R A C T
This paper evaluates low-carbon urban development strategies for the transport sector in São Paulo, one of the largest cities in the world. For each mobility policy selected, we build scenarios to evaluate the potential of mitigating GHG emissions, shedding light on institutional aspects, benefits and risks of implementing each measure. Selected policies analyzed in this paper focus on: (i) reduction of frequency and distance of motorized trips; (ii) improvement of public transport; and (ii) technological issues, from improvement of fuel efficiency of all transport modes to replacement of fossil fuels by biofuels. Results show that the measures that present the highest potential to reduce GHG emissions are those that promote the use of biofuels, particularly ethanol, followed by those that favor the use of public transport. Moreover, simulations of integrated policies evidence that their effectiveness depends upon the adoption of coordinated policies at Federal, State and Local levels. Lastly, we highlight the complementary nature of the proposed policies and the contribution of scenario building to the debate on the strategic planning of integrated urban public policies to promote sustainable development in São Paulo City.
\end{abstract}

(C) 2016 Elsevier Inc. All rights reserved.

\section{Introduction}

Climate change has become a crucial issue in the pursuit of a sustainable urban and territorial planning, especially in big cities, where the formulation and implementation of measures of mitigation and adaptation to climate change have become mandatory (Rodríguez, 2013, Samaniego et al., 2013).

In this context, urban transport systems play a key role in sustainable development. Besides affecting productivity and supporting other productive sectors through urban integration, transport is one of the sectors that accounts for a huge volume of GHG emissions. Although in Brazil most emissions are associated with changes in land use due to deforestation and agriculture (MCT, 2013), in a big city like São Paulo, which has a population of more than eleven million people in 2011 (IBGE) and one of the highest average time spent in commuting, ${ }^{1}$

\footnotetext{
th Low-carbon policy scenarios in urban transport

* Corresponding author.

E-mail addresses: emenezes@sp.gov.br (E. Menezes),gori@eco.unicamp.br (A.G. Maia).

1 The average time spent commuting was more than 50 min in 2012 in São Paulo Metropolitan Area METRO (2012a).
}

most GHG emissions are generated by the urban transport sector (Ekos-Geoklock, 2013).

For these reasons, mitigation of GHG emissions has been integrating urban planning aims and goals, especially in proposals for the transport sector in metropolitan areas (World Bank, 2011). The evaluation of the effectiveness of these strategies requires studies of mitigating potential according to local market, technology and economic context. The implementation of such measures also depends on the coordination of actions among different institutional and governmental spheres (Federal, State and Local).

Analyses showing how feasible it would be to reach a given goal of GHG emission reduction through selected measures would be quite useful as guidance to policy prioritization, planning and execution. However, the complex interactions among policies and institutions have barely integrated into specific assessments of policy effectiveness to reduce GHG emissions in São Paulo City's transport.

Contributing to this efforts, this paper assesses impacts of lowcarbon development strategies on the GHG emissions from the transport sector in the city of São Paulo. First, we reviewed the research literature in order to collect the most common policy measures to reduce GHG emissions from transport; second, we consulted public managers at São Paulo City Hall in order to select the most suitable policies for 
the city among those previously selected in the literature. Then we analyze the selected measures through scenario building, made with the support of a dynamic simulation model. Selected measures evaluated in this paper refer predominantly to passenger modes and focus on: (i) reduction of frequency and distance of motorized trips, especially of personal vehicles; (ii) stimulus to use public transport; and (iii) technological issues, from improvement of energy efficiency of selected transport modes to incentives to replace fossil fuels with biofuels.

Our hypothesis is that the adoption of just one type of policy - technological, regulatory or of management - is not enough to reach the desirable goals of GHG mitigation in the city. The analysis of the policy scenarios provides a glimpse of the potential impacts of low-carbon mobility policies on GHG emissions and a basis for discussion on strategic planning of urban public policies. It also provides valuable insights to select appropriately the best solutions among the main available options, in accordance to the goal of promoting urban sustainable development in São Paulo City.

In the following sections, we present a brief description of São Paulo's low-carbon initiatives in the last decade and the procedures taken for the policy scenario building and evaluation. Then we present details about the dynamic simulation tool chosen to build policy scenarios, as well the data collected for such a purpose. In sequence, analyses compare business-as-usual and policy scenarios in order to evaluate the relative potential effectiveness of the selected measures. Lastly, we analyze the simulated scenarios and recommend actions for policymakers. We also shed light on institutional issues of policy implementation, which is essential to the feasibility of the proposed public policies. With these results, we expect to contribute in sensitizing policymakers to the potential impacts brought about by selected measures and to the need to integrate them into a single future scenario so as to get the closest results to the City's goals of GHG mitigation.

\section{Planning low carbon strategies in the São Paulo context}

São Paulo's fast urban growth, especially in the 1970s and 1980s, associated with poor planning and organization, largely explain the challenging problems faced by the City in recent years. Inadequate urban infrastructure, the chaotic urban mobility and a concentration of activities in São Paulo Metropolitan Area brought intense traffic congestions (Carvalho, 2014) and worsened considerably the quality of air (CETESB, 2011b).

São Paulo City, which is the São Paulo State Capital, was one of the first megacities in Latin America to include climate change issues in its management process. In 2005, São Paulo published its first inventory of GHG emissions. The energy sector presented the highest GHG emissions in the city ( $76 \%$ of the total), including transport, which alone accounted for $68 \%$ of total emissions (SMVMA, 2005).

In 2009, the State Capital launched a pioneering Brazilian local climate change policy and defined by law ${ }^{2}$ a goal of $30 \%$ of reduction in GHG emissions in 2012 compared to 2003. Two years later, São Paulo City Committee on Climate Change and Eco-Economy published an Action Plan for mitigation and adaptation through a set of guidelines for the main public sectors to minimize emissions, thus adapting to cope with climate change (São Paulo, 2011). Nevertheless, according to data from the second Inventory of GHG emissions in São Paulo City, launched in 2013 (Ekos-Geoklock, 2013), total GHG emissions from energy and waste rose about $8.7 \%$ from 2003 to 2011. Emissions rose 10\% from 2010 to 2011, and 7\% between 2009 and 2010. Only in 2006 and 2009 (a recession year) did GHG emissions annual growth drop. Gasoline, ethanol and diesel combustion for the transport sector accounted for 61\% of GHG emissions from 2003 and 2011 and for a growth of $24.7 \%$ in emissions in the same period. Therefore, considering São Paulo City's transport sector only, the GHG emissions trend shows that the State

\footnotetext{
2 Municipal Law 14.933, 2009.
}

Capital could hardly have reached the goal of a 30\% reduction by 2012 as laid down by legal norms.

Such an evolution of GHG emissions indicates that public policies may have a crucial role stimulating the reduction of GHG emissions, which motivated São Paulo City Government efforts to put the city on a trajectory of low-carbon development. This context opened an opportunity for the Economic Commission for Latin America and Caribbean (ECLAC) to propose a protocol of intentions to the São Paulo City Public Administration, with the purpose of promoting cooperation between these two entities in studies on themes related to Urban Development. In this framework, ECLAC presented its project "Low Carbon Paths to Development" to technical managers from diverse sectors of local public administration, such as transports, urban services and environment. As the transport sector is the main responsible for GHG emissions in the city, ECLAC proposed to evaluate the impact of specific public policies on this sector. In next section, we present the methodology employed to develop such policy evaluation.

\section{Methodology of the study}

The main purpose of the policy evaluation proposed by ECLAC to São Paulo local government was sensitizing stakeholders to the potential impacts of these policies and their implications to decision making. To accomplish such purpose, an outline of policy scenarios chosen as the most plausible solution for GHG mitigation of São Paulo City was elaborated. This procedure was part of an important stage of low-carbon strategic planning to mitigate GHG emissions from São Paulo City's transport sector, basically consisting of scenario building through dynamic simulations.

The first step was to elaborate a range of options for low-carbon paths for the transport sector, based on an extensive research in the literature (for example, Samaniego et al., 2013World Bank, 2011) and on current policies and strategies in São Paulo's transport sector to reduce carbon emissions. Then we held discussions with representatives of São Paulo City Hall, especially from the Departments of Environment, Services and Transport, in order to select the most suitable strategic proposals. The selected low-carbon policies were the following: i) Promotion of teleworking; ii) Incentive of shared private transport; iii) Improvements in public transport; iv) Incentive to improve efficiency of vehicles; and v) Increase in the use of biofuels. The first and second proposals are predominantly of regulatory nature, i.e., they depend mostly on revision of current labor laws and traffic norms. The third measure relates to management and investments in public transport. The others involve fiscal and economic incentives for technological development related to automobile and fuel industries.As a goal underlying the aim of GHG reduction, we take as reference the desirable level of emissions in São Paulo City stated as being 30\% lower in 2012 compared to 2003.

Having established this goal, the next step was to build, with a dynamic simulation model, the business-as-usual (BAU) scenario as reference to compare with the possible effects of policy implementation. Next, policy scenarios were built and analyzed taking into account their feasibility of implementation, and institutional and political obstacles and risks. The results are compared with evidences found in literature.

Such planning and evaluation process is not linear. The analysis cycle may restart with feedbacks from the policy scenario analysis. The idea is to reassess the selected policies in light of the results from the former impact analysis, in order to improve or replace them by other propositions. It is a learning process, where the new propositions or reformulated ones undergo new cycles of scenario analysis, until the desirable policies are obtained in the scenario simulation environment.

There is much room for improvement and refinement of each selected measure. Successive revisions with the participation of the stakeholders are essential, especially if counting on public managers who are ultimately responsible for setting objectives and making decisions 
involving the implementation of the selected policies. In this sense, the evaluation presented in this paper corresponds to just a first phase of a longer and interactive learning and evaluation process, with the purpose to instigate discussion about the feasibility of the proposed policies and how to improve them.

\subsection{Scenario building with a dynamic simulation model}

There have been several efforts to employ system dynamics tools to evaluate environmental policies (for example, see Musango et al., 2014, Fong et al., 2009 and UNEP, 2011). ${ }^{3}$ In particular, specific tools have been developed to assess the impacts of public policies on carbon emissions from the transport systems. Although these dynamic models are very heterogeneous, all of them are composed by integrated modules representing the main elements of a transport sector: economy, population, vehicle fleets, technology, demand for transport services and environment. Table 1 exhibits the most common modules of these simulation tools and their usual input parameters. These models allow users to put selected data in order to simulate a hypothetical situation in a given context.

The main differences among simulation tools lie in the emphasis on one or other aspect of a transport system. Many researchers propose their own system dynamic model adapted to their specific context and issues (for example, Feng et al. 2012, Li et al., 2012, Liu et al., 2015, Sabounchi et al., 2014 and Wang et al., 2008). In turn, as examples of research based on preexisting system dynamic models, one can mention Fiorello et al. (2010), who employ ASTRA (ASsessment of TRAnsport Strategies), a model that deals with the economy through two modules: the macro economy, which includes detailed macroeconomic variables, from economic growth to employment rates and trade sector; and the regional economy, in order to estimate the spatial distribution of passengers and freight circulation. In turn, Pfaffenbichler et al. (2010) use another tool, MARS (Metropolitan Activity Relocation Simulator), whose prominent feature is the land use module, which influences demand for transport and congestion trends. Both tools require several data on costs for housing, average living space, shares of production sectors, workplaces, share of area occupied by workplaces, among others. Andrejszk et al. (2014a) and Commander et al. (2015) chose ForFITS (For Future Inland Transport Systems): the former, to evaluate impacts of selected policies on GHG emissions in Hungary, and the latter to estimate the effects of fuel subsidies and of oil prices on pollution and GHG emissions, as well on the choice of intermodal services in the City of Cairo (Egypt).

There are several advantages of using preexisting simulation models. They have embedded knowledge that the team of developers had to have or acquire in order to develop them, so using a preexistent model enables the researcher to take profit of such built-in knowledge. Many simulation models are sponsored by research institutions that make them freely available to researches, besides offering a support team to update the models and help users, which increase the chance of using these tools. Moreover, these models are developed to be suitable to different contexts and purposes to be easily adopted, besides favoring eventual comparative studies as they are used.

To develop the simulations presented in this paper, we chose the abovementioned ForFITS, ${ }^{4}$ a system dynamic model developed for UNECE (United Nations Economic Commission for Europe) and the Regional Commissions of the United Nations (UNECE, 2011a). UNECE's motivation to develop a new tool was to use a simulation model that contemplates most of the features of available tools to evaluate strategies for sustainable and integrated development of

\footnotetext{
${ }^{3}$ A comprehensive study on the applications of the system dynamics approach can be found in (Sterman, 2000)

${ }^{4}$ ForFITS is freely downloadable at www.unece.org/trans/theme_ForFITS.html.
}

Table 1

Usual modules and input parameters present in most transport system simulation tools. Source: Devised by authors based on available simulation tools.

\begin{tabular}{|c|c|}
\hline Module & Parameters \\
\hline Economy & $\begin{array}{l}\text { GDP per capita and growth projections; projections of inflation; } \\
\text { economic sectors, trade; employment }\end{array}$ \\
\hline Population & Population in the base year and growth projections \\
\hline Vehicle fleets & $\begin{array}{l}\text { Fleets per type of vehicle, mode (air, terrestrial, hydric) and } \\
\text { service (passenger and freight) }\end{array}$ \\
\hline Technology & $\begin{array}{l}\text { Types of fuel (gasoline, diesel, biofuels); types of motors (internal } \\
\text { combustion engines, hybrid, electric, fuel cells); evolution of } \\
\text { efficiency of motors; technology choices. }\end{array}$ \\
\hline $\begin{array}{l}\text { Demand and } \\
\text { supply }\end{array}$ & $\begin{array}{l}\text { New registrations of vehicle per type, mode and service; intensity } \\
\text { of use (average distance traveled per year per vehicle, including } \\
\text { non-motorized); vehicle load (number of passengers and freight } \\
\text { weight); market share of public transport (bus and rail); costs of } \\
\text { vehicles, fuels, public transport tickets and congestion prices }\end{array}$ \\
\hline Environment & $\begin{array}{l}\text { Energy and fuel consumption per vehicle per type; GHG emission } \\
\text { factors per type of fuel }\end{array}$ \\
\hline Other & $\begin{array}{l}\text { Modules simulating impacts of land use on transport demand, } \\
\text { which include parameters such as employment, household } \\
\text { income, costs for housing, average living space, shares of } \\
\text { production sectors, workplaces, share of area occupied by } \\
\text { workplaces }\end{array}$ \\
\hline
\end{tabular}

various transport modes, applicable to the most diverse local, regional and national contexts (Andrejszk et al., 2014b). Furthermore, the development of ForFITS should produce internationally comparable results, a criterion which, according to UNECE (2011a) none of the existing tools met.

ForFITS was developed upon Vensim Software ${ }^{5}$ that allows us to assess possible impacts of public policies on the demand for public and private transportation, the intensity of use by mode (cars, trains, buses, and trucks), energy consumption and GHG emissions, among other relevant variables. In a pilot study that included seven selected countries from each region of the world, ${ }^{6}$ UNECE tested several scenarios to demonstrate the usefulness of the tool and to assure its applicability to different regional contexts (UNECE, 2013). In the case of São Paulo City, the results are part of a pioneering study of applying ForFITS to assess the impact of public policy on GHG emissions from transport in a big metropolitan city.

One of the main advantages of ForFITS is its integrated representation of most relevant aspects that define a transport system and its resulting GHG emissions conditioned by technological and socioeconomic issues. In order to predict GHG emissions, ForFITS employs input data on technical specifications of available motor technologies (for example, ignition motors, electric and hybrid), fuels (energetic potential and GHG emissions per liter consumed), the amount of vehicles on the road by category (light vehicle, motorcycle, truck, bus), modes (on wheels or trains) and type of service (public or private). It also considers characteristics of the demand system to be simulated, such as GDP per capita and demographic trends.

Using ForFITS enables exploring the feedback effects of relations of cause and effect between demands for transport services and the urban transportation sector. Moreover, many of common features of all transport modes are consolidated in this model, which makes its use very practical. The model requires socioeconomic data entry that characterize the region to be evaluated - in the case of this work, the City of São Paulo, and technical information relating to the consumption of fuel and energy and GHG emissions per vehicle category and

\footnotetext{
${ }^{5}$ Vensim is a free software that can be used to develop simulation models for diverse applications. More information can be consulted at Vensim's website: http://vensim. com/vensim-software/(access in: Dec. 28, 2015).

6 The selected countries of UNECE's pilot report were Chile, Ethiopia, France, Hungary, Montenegro, Thailand and Tunisia.
} 
emission factors according to fuel used. ForFITS estimates the demand for each transport mode based on projections of GDP, population, economic growth, price inflation and on international cases consolidated in statistical studies, which identify the relationship between market share and GDP per capita from sectorial time series analysis. With these data, the model projects a logistic or S-shaped demand curve, represented by the diffusion of new vehicles in the market (of all passengers and freight modes). ${ }^{7}$

\subsection{Building policy scenarios for São Paulo City: input and output parameters}

Table 2 depicts the relation of the main input parameters, which describes São Paulo City's transport sector, and the sources of information. Many other input parameters are available at ForFITS to be filled out by the user; for the purposes of this paper, the table contains only those parameters whose values we informed.

The ForFITS outputs used in these analyses are the following:

1) Total pkm (passenger.kilometer): indicates the intensity of use of passenger transport modes, calculated by the number of passengers multiplied by the distance covered in a year. The higher the $\mathrm{pkm}$, the more intense is the use of a given mode. In turn, intensity of use per vehicle (i.e the distance covered in a year per vehicle) is an exogenous input (introduced in ForFITS by user) which remains constant as demand does not affect it. In turn, tkm (tons.kilometer) is the indicator of intensity of use for freight transport.

2) Total energy used by passenger and freight transport, in tons of oil equivalent (toe): reflects the average consumption of fuel and electricity.

3) GHG emissions, divided into three types, according to the fuel life cycle phase when they are generated:

I. Tank to wheel (or TTW) emissions: generated from fuel or energy consumption. TTW GHG emissions is compatible to emissions from transports estimated to the inventory of São Paulo City (Ekos-Geoklock, 2013).

II. Well to tank (or WTT) emissions: generated during the production phase; $^{8}$

III. Well to wheel (or WTW) emissions: generated during the complete fuel life cycle, composed of production and consumption. They result from the sum of TTW and WTT GHG emissions.

ForFITS estimates emissions from each vehicle of São Paulo's active fleet, fuel consumption per vehicle, annual travel per vehicle ( $\mathrm{km}$ per year) and the intensity of use and fuel consumption of vehicles. These estimates differ from some inventories of GHG, such as CETESB (2011a) and Ekos-Geoklock (2013), which calculate GHG emissions based on the city's total fuel consumption and the emission factor per type of fuel. Therefore, differences between ForFITS base-year results and estimates from inventories may arise. The differences tend to be more relevant for freight vehicles, since ForFITS uses the average distance traveled per year per vehicle to estimate emissions, whereas inventories use the total fuel marketed in São Paulo City only. Therefore, as freight vehicles travel long distances outside the capital, part of the fuel is not included in São Paulo City's total fuel consumption considered by inventories. In turn, ForFITS considers the whole distance traveled per vehicle. As there is no information about the proportion of fuel

\footnotetext{
${ }^{7}$ Detailed information on the operating characteristics of ForFITS can be found at UNECE (2011b).

${ }^{8}$ Values of WTT carbon emissions factors for gasoline and ethanol from sugarcane were obtained directly from the technicians of UNECE responsible for the development of ForFITS.
}

Table 2

ForFITS main input parameters and sources.

Source: devised by the authors.

\begin{tabular}{|c|c|c|}
\hline & Input parameter & Sources and estimatives \\
\hline \multirow[t]{2}{*}{$\begin{array}{l}\text { Socioeconomic } \\
\text { variables }\end{array}$} & $\begin{array}{l}\text { Population and populational } \\
\text { projection }\end{array}$ & $\begin{array}{l}\text { Sao Paulo's Foundation State } \\
\text { System of Data Analysis } \\
\text { (SEADE), Brazilian Institute of } \\
\text { Geography and Statistics (IBGE) }\end{array}$ \\
\hline & $\begin{array}{l}\text { Local GDP and growth } \\
\text { projections }\end{array}$ & $\begin{array}{l}\text { SEADE, IBGE, Brazilian Central } \\
\text { Bank }\end{array}$ \\
\hline \multirow[t]{8}{*}{$\begin{array}{l}\text { Sectorial } \\
\text { variables }\end{array}$} & $\begin{array}{l}\text { Stock of vehicles actually in use } \\
\text { by category and fuel (gasoline, } \\
\text { ethanol, diesel, electricity) } \\
\text { - Mode included: motorcycles } \\
\text { and light and commercial } \\
\text { vehicles, buses, trucks and } \\
\text { passenger trains (subways and } \\
\text { commuter trains) }\end{array}$ & $\begin{array}{l}\text { CETESB (2011a), STM (2013), } \\
\text { METRO (2012a) }\end{array}$ \\
\hline & $\begin{array}{l}\text { New registered vehicles (base } \\
\text { year, base year minus five, base } \\
\text { year minus ten) }\end{array}$ & $\begin{array}{l}\text { Brazilian Traffic Deparment } \\
\text { (DENATRAN) }\end{array}$ \\
\hline & $\begin{array}{l}\text { Intensity of use per vehicle, } \\
\text { category and average age } \\
\text { (average annual travel per } \\
\text { vehicle) }\end{array}$ & $\begin{array}{l}\text { CETESB (2011a), MMA (2011), } \\
\text { METRO (2012b) }\end{array}$ \\
\hline & $\begin{array}{l}\text { Fuel consumption per type of } \\
\text { vehicle }\end{array}$ & \\
\hline & Average number of passengers & METRO (2012a), Sao Paulo \\
\hline & and weight of freight per mode & $\begin{array}{l}\text { Metropolitan Train Company } \\
\text { (CPTM), Sao Paulo City } \\
\text { Transportation Corporation } \\
\text { (SPTrans), EMPLASA (2006) }\end{array}$ \\
\hline & Fuel prices and taxes & ANP (2015) \\
\hline & $\begin{array}{l}\text { GHG emission factors per fuel } \\
\text { type }\end{array}$ & $\begin{array}{l}\text { CETESB (2012), MMA (2011), } \\
\text { Carvalho (2012), Edwards et al. } \\
\text { (2006), UNECE }\end{array}$ \\
\hline
\end{tabular}

acquired in transit out of the State Capital, it is not possible to exclude such a proportion of consumed fuel from ForFITS estimates, which difficult a comparison between ForFITS projections and GHG inventories. On the other hand, light vehicles and motorcycles present a much lower intensity of use, which indicates that, for these modes, the local use prevails and, hence, that most fuel provided for light vehicles and motorcycles is bought in the State Capital.

ForFITS default hypothesis for rates of incremental improvements in motor technology states that, in 2025, energy efficiency would reach levels roughly $20 \%$ to $25 \%$ higher than the levels seen in the base year (2010) for light vehicles; from 10\% to 15\% higher for motorcycles; and up to 5\% for heavier vehicles. From 2025 through 2040, the improvement in energy efficiency would grow between $5 \%$ and $10 \%$ (UNECE, 2011b). It is worth noticing that these hypotheses are consistent with the Inovar-Auto, a Brazilian Government Program whose minimum goal of energy efficiency gain is $12.08 \%$ by 2017 (MDIC, 2012). The higher the level of energy efficiency, the lower is the fuel consumption of a new vehicle.

WTW GHG emission factor for passenger rail systems is near zero, as passenger rail in Brazil is powered mostly by hydropower (which has negligible GHG emissions). However, emission factors of subway companies fluctuated intensely between 2008 and 2012 due to wide variations in composition of the matrix of primary sources used to generate electricity in Brazil in those years (METRO, 2012a). If the demand for electricity surpasses the capacity to generate hydropower energy, Brazil's National Interconnected System (SIN) puts fossil fuel power plants into operation, which results in carbon emissions at higher levels. Nevertheless, the emission factor per passenger remains much smaller than that observed for transport on wheels. In this work, we chose to employ the carbon emission factor reported in 2010, the base year, when hydropower energy prevailed. In addition, we suppose that the 
Table 3

BAU Scenario: main results of São Paulo transport sector. ${ }^{\text {a }}$

Source: devised by the authors using ForFITS.

\begin{tabular}{|c|c|c|c|c|}
\hline \multicolumn{5}{|l|}{ BAU scenario } \\
\hline Variables & Unit & Base year & 2040 & Rate 2040/base year \\
\hline Total pkm (passenger.kilometer) & Pkm, billion & 179 & 312 & 1.7 \\
\hline Total tkm (ton.kilometer) & Tkm, billion & 37 & 93 & 2.5 \\
\hline Total energy used - passenger and freight modes & Toe, million & 6 & 13 & 2.2 \\
\hline GHG emissions TTW - Total & $\mathrm{kg} \mathrm{CO}_{2} \mathrm{e}$, billion & 14 & 31 & 2.3 \\
\hline GHG emissions TTW - passenger modes only & & 7 & 13 & 1.8 \\
\hline GHG emissions WTW - Total & & 17 & 38 & 2.2 \\
\hline GHG emissions WTW - passenger modes only & & 9 & 16 & 1.8 \\
\hline
\end{tabular}

a This table of results is similar to that used by UNECE's pilot study with ForFITS applied to several countries (UNECE, 2013).

average energy matrix would not change substantially along the simulation period (2010 to 2040).

\subsection{The business-as-usual (BAU) scenario}

Table 3 summarizes the main results of the simulation of GHG emissions by the urban transport sector in São Paulo City in a trend or BAU scenario, i.e. in the absence of new policy interventions. The "base year" column contains the values of the main outcome variables (described in Subsection 3.2) in the first year of simulation (2010). The column "2040" contains the values of the output variables in the year 2040. The "2040 Rate/Base Year" column shows the magnitude of variation of the annual output at the end of the simulation period compared to baseline.

In the BAU scenario, in 2040 most variables reach values near the double of that in base year, showing that the goal of a $30 \%$ reduction in GHG emissions (mentioned in Section 2) is a huge challenge.

Results from this scenario was driven mostly by the average GDP growth, supposed to grow around 2.6 times in the simulation period. ${ }^{9}$ This result is consistent with the reference scenarios of the selected countries presented in UNECE (2013). Countries that expect high economic growth presented higher ratio between emissions in 2040 and in base year: for example, Chile would expect a GDP more than four times higher in 2040 than in the base year, and energy use and GHG emissions (in $\left.\mathrm{CO}_{2} \mathrm{e} / \operatorname{lge}\right)^{10}$ are around five times higher at the last year of simulation. In turn, among those countries that expect a relatively low GDP growth, France would have its GHG emissions in 2040 just $7 \%$ higher than in the base year, and Hungary, which also supposes a slight decline in population in the period, reaches a WTW GHG emissions level $29 \%$ lower in 2040.

The energy used in tons of oil equivalent (toe) reflects the average consumption of fuel and electricity, which in turn affects the rate of increase in GHG emissions in a similar proportion: in thirty years, the emissions per year would reach a level more than twice the level of 2010. Comparing emissions from consumption of fuels and electricity to the total emissions, generated during the fuel production and consumption phase (i.e., well to wheel or WTW), one realizes that most emissions occur at the consumption phase (i.e., tank-to-wheel or TTW), when combustion occurs. Passenger modes account for about half of GHG emissions in 2010, but their share decreases slightly, reaching about $42 \%$ of total at the end of the simulation period.

\footnotetext{
9 The average GDP growth for the simulation period was defined as $2.24 \%$ in the period 2010-2015 and 3.5\% from 2018, according to Brazil's Central Bank Balance of Payments Bulletin until 2013 and projections from 2014 by Brazil's Central Bank Focus (from market expectations in February 21, 2014).

${ }^{10}$ Carbon equivalent, or $\mathrm{CO}_{2} \mathrm{e}$, is a unit of GHG, based on equivalence of the global warming potential of greenhouse gases as a function of its global warming potential compared to that of carbon dioxide (IPCC, 2006); lge is the abbreviation of "liter of gasoline equivalent", which means the amount of a fuel whose quantity of energy equals to that contained in one liter of gasoline.
}

Table 4 shows the trends for fleets by mode (motorcycle, light vehicles, bus, train, trucks and commercial) and service (passenger and freight). In BAU scenario, vehicle fleets grow significantly, given São Paulo's population and Brazilian economic growth projections (which are exogenous parameters in ForFITS), as well as the current transport share of pkm by mode, which remains constant (with the base year value). Most of the growth in the intensity of use, indicated by pkm, occurs in the bus mode, showing the relevance of this mode in the current system structure. On the other hand, the intensity of use of light vehicles such as private cars is remarkable, and its share on GHG emissions (in percentage on total of $\mathrm{kg} \mathrm{CO} \mathrm{CO}_{2} \mathrm{e} / \mathrm{lge}$ ) among passenger modes is much higher than buses' share in 2010 as well in 2040.

With respect to passenger rail system (metropolitan trains and subway system), variation in stock of trains represents the expansion of the whole rail system in São Paulo City. In spite of the importance of the passenger rail to public transport system, its intensity of use is relatively low compared to other modes, and its GHG emissions are much lower than other energy sources, given that São Paulo's passenger rail system is powered by electricity (mostly generated from hydroelectric plants).

In freight transport, the increase of the intensity of use occurs mainly with trucks, which are the mode with the biggest share of GHG emissions. Overall, results indicate that: i) most GHG emissions derived from light vehicles and trucks, and ii) there would be a trend of increasing GHG emissions share of freight services in the long run.

Energy consumption per mode explains part of GHG emissions trend. Light vehicles account for most of the energy consumed among passenger modes, followed by buses and motorcycles. Taking into account the intensity of use, we note that more energy is expended in a mode with relatively low number of passengers transported per vehicle, i.e., most of the energy is being used in a mode whose passenger carrying capacity is much more limited. In freight service, energy consumption by light commercial vehicles grows faster than the trucks, which still predominate. It should be noted that many light commercial vehicles are used as passenger vehicles, so it is uncertain the apparent trend of trucks being outstripped by light commercial vehicles in freight transportation in the long term.

Overall, the BAU scenario projections until 2040 show that São Paulo City's GHG emissions do not seem to approximate to the required rate of reduction to reach the goals stated in local level (according to Municipal Law 14.933, 2009). On the contrary, in 2040 overall emissions more than double compared to the base year. Therefore, results of BAU scenario highlight the need to foster GHG emissions reduction though governmental action andconstitute the baseline of an assessment of policy scenarios, whose results, projected using ForFITS, are presented in the following section.

\section{Impact analysis of policies to mitigate GHG emissions}

Measures aiming to intervene in the transport system in order to reduce GHG emissions would result in changes in one or more ForFITS input parameters. 
Table 4

Projection of the evolution of São Paulo City's transport system indicators - BAU scenario.

Source: devised by the authors with results from ForFITS simulations.

\begin{tabular}{|c|c|c|c|c|c|c|c|c|c|c|c|}
\hline \multirow[t]{3}{*}{ Service } & \multirow[t]{3}{*}{ Mode } & \multirow{2}{*}{\multicolumn{2}{|c|}{ Fleet (thousands) }} & \multirow{2}{*}{\multicolumn{2}{|c|}{$\begin{array}{l}\text { pkm or tkm } \\
\text { (billion) }\end{array}$}} & \multirow{2}{*}{\multicolumn{2}{|c|}{$\begin{array}{l}\text { Share on energy } \\
\text { consumption (\%) }\end{array}$}} & \multicolumn{4}{|c|}{ Share on GHG emission (\%) } \\
\hline & & & & & & & & \multicolumn{2}{|c|}{ Tank-to-wheel } & \multicolumn{2}{|c|}{ Well-to-wheel } \\
\hline & & 2010 & 2040 & 2010 & 2040 & 2010 & 2040 & 2010 & 2040 & 2010 & 2040 \\
\hline \multirow[t]{4}{*}{ Passenger } & Motorcycle & 458 & 878 & 4 & 8 & $1 \%$ & $1 \%$ & $1 \%$ & $1 \%$ & $1 \%$ & $1 \%$ \\
\hline & Light vehicle & 3199 & 8064 & 55 & 108 & $44 \%$ & $38 \%$ & $28 \%$ & $24 \%$ & $29 \%$ & $26 \%$ \\
\hline & Bus & 33 & 54 & 104 & 169 & $16 \%$ & $12 \%$ & $24 \%$ & $17 \%$ & $23 \%$ & $17 \%$ \\
\hline & Train & 0,231 & 0,380 & 16 & 27 & $2 \%$ & $1 \%$ & $0 \%$ & $0 \%$ & $0 \%$ & $0 \%$ \\
\hline \multirow[t]{2}{*}{ Freight } & Truck & 90 & 232 & 28 & 73 & $27 \%$ & $29 \%$ & $39 \%$ & $43 \%$ & $38 \%$ & $42 \%$ \\
\hline & Light commercial & 494 & 2411 & 8 & 20 & $10 \%$ & $19 \%$ & $8 \%$ & $15 \%$ & $8 \%$ & $15 \%$ \\
\hline TOTAL & & - & - & - & - & $100 \%$ & $100 \%$ & $100 \%$ & $100 \%$ & $100 \%$ & $100 \%$ \\
\hline
\end{tabular}

Table 5 exhibits the selected policies and their predominant type, as well the associated input parameters to be changed according to the policy adopted. Each parameter can be changed by one or more measures to mitigate GHG emission from the transport sector. Associated with distinct scenarios, we evaluate the expected effects of each policy against BAU scenario. In the following subsections, the selected scenarios are described, as well how each parameter was chosen and their values was set, taking as reference information found in literature.

\subsection{Promoting teleworking}

Teleworking or telecommuting means working from home or elsewhere outside the workplace of the company with which the employee has a work contract. Enabled by telecommunication and information technologies (ICTs), teleworking can be disseminated among workers whose functions are possible to perform without the need for his or her constant presence at workplace. Measures to encourage teleworking could interfere in the number of trips per person in a city and, therefore, in GHG emissions from transport.

According to a study about teleworking in United States, the proportion of workers who worked exclusively at home grew from $4.8 \%$ in 1997 to 6.6\% in 2010 (Mateyka et al., 2012). The proportion of workers who worked at home at least one full day a week grew from $2.2 \%$ in 1997 to $2.8 \%$. Another study showed that, in $2014,23 \%$ of employed persons living in U.S. metropolitan areas did some or all of their work at home, while in 2003 this proportion was 19\% (BLS, 2015). In United Kingdom, from January to March 2014, among people in work, the proportion of people who worked at home for at least half of their work time was $13.9 \%$, against $11.1 \%$ from January to March 1998 (Office of National Statistics, 2014).

These findings are consistent with the trends highlighted by another survey about teleworking carried out in 24 countries (Ipsos, 2011). According to this survey, $5 \%$ of American workers telecommuted, and $4 \%$ worked fully from home in 2011. Considering the average of selected countries, $35 \%$ of workers telecommuted, and $7 \%$ worked every day from home. In Brazil, these proportions were, respectively, $28 \%$ and $9 \%$.

Many telework experiences have been implemented in private companies and in the public sector (Lister and Harnish, 2011; OPM,
2013), motivated by its potential benefits, such as office's maintenance and transport costs reduction. With less vehicles circulating, overall congestion tends to reduce, as well air pollution and GHG emissions. On the other hand, some factors may limit the potential of expansion of telework, such as management and safety concerns; moreover, telework may induce energy consumption at home and other travels not related to work, which may attenuate its positive effects over reducing costs to workers and GHG emissions (Kitou and Horvath, 2008).

With respect to the impacts of teleworking on GHG emissions, a study with 933 Federal civil teleworkers in the US suggests that they were responsible for savings of 104,000 gal of gasoline, 2.4 million commute miles and 578 millions of tons of carbon emissions in 2012 (OPM, 2013). In fact, teleworking can reduce substantially the average distance traveled by the teleworkers, but in the aggregated level, such impact may be diluted. Based on a time-series analysis with nationwide data, Choo et al. (2005) concluded that the reduction in U.S. total vehicle miles traveled due to telework in the period 1966-1999 is statistically significant, around $0.78 \%$, which allowed the authors to consider telework as a cost-effective policy in face of government expenses on public transport. In turn, Kitou and Horvath (2008) found that $\mathrm{CO}_{2}$ emissions in a 3-day teleworking scenario would be $5 \%$ to $11 \%$ lower than in a non-teleworking one, in average of selected American States.

Studies quantifying costs and benefits of teleworking experiences in Brazil are still scarce, though there have been ongoing pilot experiences (SMA, 2013). One can assume that teleworking potential may expand in Brazil enabled by ICT's diffusion and pushed by the huge traffic problems faced by the citizens in Brazilian metropolitan areas. Despite the absence of more accurate estimates, we could suppose that São Paulo has a teleworking potential similar to the average of countries selected by Ipsos' survey (Ipsos, 2011), i.e. 35\%. To reach this potential, São Paulo would have to adopt measures to promote an increase of at least $20 \%$ of its proportion of teleworkers ( $28 \%$ of workforce in 2011 according to Ipsos, 2011). As the reduction of the number of commutes is a function of the average number of weekdays that workers do their work from home (i.e. from one to five days), we can suppose that, on average, teleworkers would work from home half of their time, i.e. 2.5 days per week. This would provoke a reduction of $50 \%$ on the average annual

Table 5

Measures to mitigate GHG emission and associated input parameters of ForFITS model.

\begin{tabular}{|c|c|c|c|}
\hline \multicolumn{2}{|l|}{ Policy } & \multirow{2}{*}{$\begin{array}{l}\text { Change to be made in parameters of ForFITS } \\
\text { simulation model }\end{array}$} & \multirow[t]{2}{*}{ Expected effect } \\
\hline Predominant type & Description & & \\
\hline \multirow[t]{3}{*}{$\begin{array}{l}\text { Regulatory and } \\
\text { management }\end{array}$} & Promoting teleworking & $\begin{array}{l}\text { Reduction in annual distance traveled per vehicle/year; } \\
\text { reduction in public transport load }\end{array}$ & Reduction in trips \\
\hline & Stimulating shared transport & Increase in the average number of passengers of light vehicles & \\
\hline & Improving urban transport system management & Passenger transport system index & Incentive to use public transport \\
\hline \multirow[t]{2}{*}{$\begin{array}{l}\text { Technological, economic } \\
\text { and fiscal }\end{array}$} & $\begin{array}{l}\text { Improving energy efficiency of } \\
\text { motorized vehicles }\end{array}$ & Increased rate of evolution of energy efficiency & $\begin{array}{l}\text { Reduction in GHG emissions } \\
\text { from fuel }\end{array}$ \\
\hline & Incentivizing biofuels & $\begin{array}{l}\text { Adjustment in the rates of variation of annual } \\
\text { emissions according to a rise in use of biofuels }\end{array}$ & \\
\hline
\end{tabular}


Table 6

Sensitivity to the variation of the average distance traveled by car and motorcycle per year and of the average occupation in buses and rails

Source: devised by authors using ForFITS.

\begin{tabular}{|c|c|c|c|c|c|}
\hline \multicolumn{6}{|c|}{ Distance in km/year per vehicle and average vehicle occupation in public transport lower than BAU scenario } \\
\hline Variables & Unit & Base year & 2040 & Rate 2040/Base year & Variation 2040/BAU scenario \\
\hline Total pkm & Pkm, billion & 168 & 293 & 1.7 & $-8 \%$ \\
\hline Total energy used - passenger and freight modes & Toe, million & 6 & 13 & 2.3 & $-1 \%$ \\
\hline GHG emissions TTW - Total & $\mathrm{kg} \mathrm{CO} 2 \mathrm{e}$, billion & 14 & 31 & 2.3 & $-1 \%$ \\
\hline GHG emissions TTW - passenger modes only & & 7 & 13 & 1.8 & $-3 \%$ \\
\hline GHG emissions WTW - Total & & 17 & 38 & 2.3 & $-1 \%$ \\
\hline GHG emissions WTW - passenger modes only & & 9 & 16 & 1.8 & $-3 \%$ \\
\hline
\end{tabular}

travel distance per teleworker in private transport, as well in the number of teleworkers using public transport. In order to simulate such scenario, the parameters related to the annual average distance traveled in light vehicles and motorcycles and to the number of passengers in public transport were adjusted to meet these hypotheses. The parameters were also adjusted to the proportion of individual motorized travels that had the work office as destiny or origin (around 53\% in 2012, according to METRO (2012a)).

The projections for the period 2010-2040 show some variation of the output parameters listed in Table 6. In 2040, total energy use by transport would be just $2 \%$ lower, and GHG emissions from passenger modes, $3 \%$ lower compared to BAU scenario. ${ }^{11}$

The suppositions about the potential of diffusion of teleworking can explain the impact of teleworking on simulation results. As Ipsos survey suggests, Brazil already has a high proportion of teleworkers (28\%) compared to the world's average (35\%). Moreover, according to a survey made by METRO (2012a), near half of travels made with private vehicles were motivated by work. Teleworking would not affect directly other relevant reasons to use transport, such as education and leisure.

The simulation would exhibit more impactful results if our supposition about potential of telework in Brazil were less conservative, considering that the proportion of teleworkers in this country could reach a proportion similar to that observed in other Latin American Countries: in Argentina, teleworkers are 45\% of country's workforce; in Mexico, 58\% (Ipsos, 2011). On the other hand, the United States already present more flexible work regulation and an extensive program of adoption of teleworking in Federal Civil Service (OPM, 2013), but they appear with just $25 \%$ of teleworkers, lower than Brazil's rate. This indicates that a reduction of the regulatory barriers to this modality of work, or its adoption by public administration, may not be enough to bring teleworking to levels that promote a more significant reduction in GHG emissions, neither the barriers such as pointed by Kitou and Horvath (2008) are easy to overcome. More studies are needed to evaluate the actual potential of teleworking in Brazil and, hence, in São Paulo City in order to have more reliable estimates of the teleworking's potential of mitigating GHG emissions.

\subsection{Incentive to use of shared private transport}

The most usual measure to incentivize shared transport consists of prioritizing private vehicles with more than two or three passengers by assigning exclusive lanes in local, urban roads or highways near urban areas(i.e. high-occupancy-vehicle lanes, or HOV lanes). The benefits are related to the attenuation of congestions and reduction of travel time and transport costs for those who share their private vehicles (carpool), as it also tend to reduce the costs with private car use. Such effect would turn HOV lanes into environmentally-friendly solution to slow traffic, as it could reduce air pollution and GHG emissions.

\footnotetext{
11 We should note that ForFITS' input on average distance per vehicle per year is constant in time; therefore, the reductions were introduced in the input parameters related to private and public transport from 2010 to 2040 as constant in time.
}

These supposed advantages have motivated the adoption of HOV lanes in many countries, especially in metropolitan areas. However, there is no consensus about the effectiveness of HOV lanes to help reducing slow traffic or to produce positive environmental effects. For example, Shewmake (2012) argues that HOV lanes could increase the vehicle miles traveled (VMT), in consequence of two factors: 1) many HOV lanes are implemented through the construction of new lanes, which expands the capacity of road; 2) when carpool increases, it improves the traffic flow and induces new demand to road use (rebound effect). On the other hand, HOV lanes help to accelerate the velocity of vehicles and, hence, may bring positive effects on the reduction of pollutants (although not in terms of GHG emissions). The author suggests that studies are still inconclusive about its benefits to traffic, air quality and if it indeed reduces the distance traveled per vehicle. Kwon and Varaiya (2008) found that HOV lanes do not seem to incentivize carpooling, although they may be useful if there are a high number of buses and vanpools circulating in these lanes. In turn, simulations made for a medium European urban city by Fontes et al. (2014) showed that the conversion of a general-purpose lane into an HOV lane could reduce the average travel time and $\mathrm{CO}_{2}$ emissions. An increase in the Average Occupancy of Vehicles from 1.5 to 1.7 persons per vehicle could reduce total emissions in $36 \%$ to $39 \%$ in urban corridors and arterial roads. These results were obtained without considering the possibility of induced demand.

In order to develop the simulation of a scenario of incentives to carpooling in São Paulo City, we assumed that measures to stimulate carpool would increase the average vehicle occupancy and, hence, reduce the quantity of vehicles in circulation in the city. To set the maximum average vehicle occupancy for simulation purposes, it should consider the effective potential of such measures to heighten the average number of passengers per vehicle. In 2007, the average vehicle occupation of a sample of European countries (UK, Denmark, The Netherlands, Norway, Germany, Austria, Spain and Italy) was 1.54, with a declining trend. ${ }^{12}$ In Los Angeles and Ventura Counties, California (U.S.), the average vehicle occupancy in the HOV lanes was 2.19 against 1.1 of mixed-flow lanes (Caltrans, 2006). In 2011, São Paulo presented a rate of 1.4 passengers per car (CET-SP, 2014), which is the value used in the BAU scenario.

It is not possible to predict the exact variation in the average number of passengers due to policies encouraging shared transport, but one can simulate the behavior of GHG emissions if the average number of passengers per car were 02 passengers per vehicle. In light of the studies mentioned above, this is a very optimistic hypothesis, but it is useful to illustrate the potential limit of such type of policy on GHG emissions. In this scenario, simulation results show that the reduction in total pkm of the passenger transport sector would reach $12 \%$ and, in GHG emissions, 4\% over all modes (passenger and freight, TTW and WTW) and $9 \%$ over TTW and WTW emissions from passenger modes only (see Table 7).

\footnotetext{
12 According to the European Environment Agency.
} 
Table 7

Sensitivity to variation in the number of passenger per vehicle.

Source: devised by the authors using ForFITS.

\begin{tabular}{|c|c|c|c|c|c|}
\hline \multicolumn{6}{|l|}{02 passengers per vehicle } \\
\hline Variables & Unit & Base year & 2040 & Rate 2040/Base year & Variation 2040/BAU scenario \\
\hline Total pkm & Pkm, billion & 202 & 276 & 1.4 & $-14 \%$ \\
\hline Total energy used - passenger and freight modes & Toe, million & 6 & 13 & 2.2 & $-2 \%$ \\
\hline GHG emissions TTW - Total & $\mathrm{kg} \mathrm{CO}_{2} \mathrm{e}$, billion & 14 & 30 & 2.2 & $-4 \%$ \\
\hline GHG emissions TTW - passenger modes only & & 7 & 12 & 1.6 & $-9 \%$ \\
\hline GHG emissions WTW - Total & & 17 & 37 & 2.2 & $-4 \%$ \\
\hline GHG emissions WTW - passenger modes only & & 9 & 15 & 1.6 & $-8 \%$ \\
\hline
\end{tabular}

Table 8

Projected evolution of indicators of São Paulo City's transport system in the scenario of incentives to shared private transport.

\begin{tabular}{|c|c|c|c|c|c|c|c|c|c|c|c|}
\hline \multirow[t]{3}{*}{ Service } & \multirow[t]{3}{*}{ Mode } & \multirow{2}{*}{\multicolumn{2}{|c|}{ Fleet (thousand) }} & \multirow{2}{*}{\multicolumn{2}{|c|}{$\begin{array}{l}\text { pkm or tkm } \\
\text { (billion) }\end{array}$}} & \multirow{2}{*}{\multicolumn{2}{|c|}{$\begin{array}{l}\text { Share on energy } \\
\text { consumption (\%) }\end{array}$}} & \multicolumn{4}{|c|}{ Share on GHG emissions (\%) } \\
\hline & & & & & & & & \multicolumn{2}{|c|}{ Tank-to-wheel } & \multicolumn{2}{|c|}{ Well-to-wheel } \\
\hline & & 2010 & 2040 & 2010 & 2040 & 2010 & 2040 & 2010 & 2040 & 2010 & 2040 \\
\hline \multirow[t]{4}{*}{ Passengers } & Motorcycle & 458 & 880 & 4 & 8 & $1 \%$ & $1 \%$ & $1 \%$ & $1 \%$ & $1 \%$ & $1 \%$ \\
\hline & Light vehicle & 3199 & 8064 & 78 & 117 & $44 \%$ & $39 \%$ & $28 \%$ & $25 \%$ & $29 \%$ & $27 \%$ \\
\hline & Bus & 33 & 41 & 104 & 130 & $16 \%$ & $9 \%$ & $24 \%$ & $14 \%$ & $23 \%$ & $13 \%$ \\
\hline & Train & 0,231 & 0,291 & 16 & 21 & $2 \%$ & $1 \%$ & $0 \%$ & $0 \%$ & $0 \%$ & $0 \%$ \\
\hline \multirow[t]{2}{*}{ Freight } & Truck & 90 & 232 & 28 & 73 & $27 \%$ & $30 \%$ & $39 \%$ & $45 \%$ & $38 \%$ & $43 \%$ \\
\hline & Light commercial & 494 & 2411 & 8 & 20 & $10 \%$ & $19 \%$ & $8 \%$ & $15 \%$ & $8 \%$ & $16 \%$ \\
\hline TOTAL & & - & - & - & - & $100 \%$ & $100 \%$ & $100 \%$ & $100 \%$ & $100 \%$ & $100 \%$ \\
\hline
\end{tabular}

Source: devised by the authors using ForFITS.

Such results do not include the potential externalities of reducing the number of vehicles on the road, neither the induced demand effect mentioned by Shewmake (2012). A fluid transit would be an additional factor in the reduction of energy consumption and carbon emissions, but an increase in the demand due to a reduction in travel time could neutralize such effect.

Table 8 shows the evolution of fleets in the tested scenario in order to clarify these results. Comparing the fleet in 2040 with the BAU scenario, relevant differences are noted only in the number of buses and trains. One explanation for this effect is the fact that the incentive to ride would cause the migration of part of current public transport users to private transport as "hitchhikers". In other words, those most benefited by the incentives to share private transport would be the users of public transportation.

Similarly, the intensity of use of light vehicles (in pkm) is substantially higher than in the BAU scenario, albeit declining over time. However, the pkm of the public transport modes in the long run reaches a much lower level than that observed in the BAU scenario. The level of energy consumed by light vehicles remains largely the same compared to the reference scenario. Nevertheless, as the intensity of use of public transport (in pkm) is lower, the energy consumption of public transport increases less, as shown by the results of Table 8 .

These trends indicate that one of the remarkable effects of the incentives to free rides might be a reduction in the demand for public transport, which is reflected in the reduction in the stock of passenger trains. Such a result probably indicates a trend under the assumption that the current structure and demand of public transport sector, reflected by the pkm of the buses and rail modes, remains stable.

\subsection{Improving public transport}

Integrated and well-coordinated management actions could improve public transport quality in São Paulo City so that it would attract more users. According to UNECE (2013), examples of measures favoring public transport over personal vehicles would be: parking and access restrictions for private vehicles; land use policies encouraging urban vertical development and mixed use areas; and improvement of the quality of services, avoiding delays and reducing time waiting. This set of measures would improve public transport efficiency, reducing traffic flow, increasing the quality of user experience and reducing time spent in motorized trips, thereby encouraging the substitution of private transport.

Other examples of such measures are proposed by the World Bank (2011) under the label "urban demand management", such as prioritization of buses on urban roads; improvement of control and limitations on the circulation of private cars in the City center; incentives to use public transportation; restrictions on use of private vehicles; congestion pricing and high prices for parking lots. It is worthwhile highlighting the importance of integrated implementation and operation of these measures because they cannot reach their full potential effects without coordination among them. With such measures, the World Bank projected a level of GHG emissions $4.6 \%$ lower than the emissions in the reference scenario in $2030 .^{13}$

The ForFITS' parameter "passenger transport system index" represents the share of pkm of public transport in total passenger transport and reflects the level of development of public transport in a given region (UNECE, 2011a). Because it is a key parameter to estimate the demand curve for public transportation in each locality, this index is used to test the impact of improving the public transport. A zero index corresponds to the situation in which all users utilize private transportation. Rural regions typically have rates close to zero, as well as cities with high spatial dispersion and little or no public transport available, or countries where fuel and private vehicles taxations are low. Many US and Canadian cities show a low passenger transport system index (UNECE, 2011a, based on 2006 data). In turn, a rate near one indicates that almost all passengers use public transport. Large cities with vertical urbanization and high-quality public transport systems tend to present an index close to 0.7 (examples: Madrid, Amsterdam, Tokyo, Buenos Aires and Johannesburg- the latter had a per capita income close to São Paulo City in 2006). Based on São Paulo's data, ForFITS estimated an index of 0.59 , not far from what would be considered a highly developed public

\footnotetext{
13 This rate was estimated by authors with World Bank simulation results for Brazilian aggregated urban areas.
} 
Table 9

Sensitivity of GHG emissions to improvements in public transport system management.

Source: devised by the authors using ForFITS.

\begin{tabular}{|c|c|c|c|c|c|}
\hline \multicolumn{6}{|l|}{ Increase of passenger transport system index (to 0.70 ) } \\
\hline Variables & Unit & Base year & 2040 & Rate 2040/Base year & Variation 2040/BAU scenario \\
\hline Total pkm & Pkm, billion & 179 & 297 & 1,7 & $-5 \%$ \\
\hline Total energy used - passenger and freight modes & Toe, million & 6 & 12 & 2,1 & $-6 \%$ \\
\hline GHG emissions TTW - Total & $\mathrm{kg} \mathrm{CO} \mathrm{C}_{2}$, billion & 14 & 30 & 2,2 & $-4 \%$ \\
\hline GHG emissions TTW - passenger modes only & & 7 & 12 & 1,6 & $-9 \%$ \\
\hline GHG emissions WTW - Total & & 17 & 37 & 2,2 & $-4 \%$ \\
\hline GHG emissions WTW - passenger modes only & & 9 & 15 & 1,6 & $-10 \%$ \\
\hline
\end{tabular}

transport, according to UNECEs' criterion.In the BAU scenario, the passenger transport system index is constant. Changes in passenger transport system index may occur after interventions that substantially improve public transport, thus encouraging the use of this service (UNECE, 2011a). In the sensitivity analysis, we added a variation factor to this index so that it increases from 0.59 in 2010 to a level of 0.7 in 2040 , similar to that observed today in cities with a highly developed public transport. The results are in Table 9. With an increase of public transport in total pkm over time, there would be reductions of $6 \%$ in total energy consumed compared to the BAU scenario, of $4 \%$ over total GHG emissions and of $10 \%$ over GHG emissions from passenger modes only.

In its pilot report, UNECE (2013) presents scenarios of growing passenger transport system index in seven countries. The growth ratio of each country was defined as $20 \%$ of the difference between the reference value of 0.7 and the country's current index value. In the case of Chile, it resulted in an index growth from 0.59 to just 0.61 (i.e., a variation of 4\%); in France (urban), from 0.47 to 0.52 (i.e., a variation of 10\%); in Hungary, from 0.13 to 0.24 (i.e., a variation of $87 \%$ ). Invariably, the higher the passenger transport system index growth, the higher the reduction in GHG emissions. In France, whose initial indexes was, respectively, 0.47 and 0.07 in urban and rural areas, an increase of $10 \%$ in these indexes resulted in a difference of two percentage points between the scenario with this index shift and the scenario without this index shift.

In the scenario of an increase in São Paulo City's passenger transport system index, the pkm share of public transport increases until 2040, but the pkm share of bus and rail modes within the public transport remains unchanged: around $14 \%$ for the rail mode, which is the current pkm share of São Paulo's urban rail system (calculated by ForFITS from input data). The reduction in GHG emissions could be higher if the pkm share of this mode could grow over the bus mode. The green line in graphs of Fig. 1 represents emissions in a scenario where the share of trains in urban public transport reaches $35 \%{ }^{14}$ by 2040 , due to investments in the expansion of passenger rail system (or subway and metropolitan train system). This result arises from the migration of part of the bus passengers to the rail system (subways and intercity trains) powered by electricity. This result is slightly better than that of increasing the passenger transport system index, depicted by the red line. The impact could be even higher in a scenario that integrates both the growth of shift of passengers both from buses to rails and from private to public transport due to a higher quality of the latter: in this scenario, GHG WTW GHG emissions would be $18 \%$ lower, according to simulation results.

According to World Bank (2011), GHG emissions would be $10.3 \%$ lower than emissions in reference scenario in $2030^{15}$ if the growth of pkm share of subways in public transport raised from $4.3 \%$ in 2006 to $14.2 \%$ in 2030.

\footnotetext{
14 This share is about half of Urban France's average, according to ForFITS data used in the UNECE's pilot study (UNECE; UNECE, 2013). France is the country among those selected in UNECE's pilot study where railroad system has the highest pkm share.

${ }^{15}$ This rate was estimated by authors with World Bank simulation results for Brazilian aggregated urban areas.
}

To sum up, to intensify the effect on the reduction of carbon emissions, it would be desirable to expand simultaneously the migration of passengers from private to public transport and from buses to trains. It would be reached combining investments in the expansion of the service capacity of the subway-railroad system, and in the quality of the public transport, encouraging users to adhere to public transportation. The likely result would be a reduction close to $20 \%$ (TTW as well WTW) in passenger modes GHG emissions when compared to the BAU scenario Fig. 1.

\subsection{Improving fuel efficiency of light and commercial light vehicles}

Fuel-efficient vehicles spend less energy and fuel and, hence, emit less air pollution and GHG. However, the overall effect of the efficiency in transports is also conditioned by other factors. First, the substitution of least efficient vehicles may occur slowly over time. Second, the benefits of fuel efficiency gains can be partially or totally offset by the "rebound effect", when the economy of energy and resources provided by the efficiency gains generates a wealth effect that stimulates further consumption of energy and resources (Alcott, 2005, Jackson, 2009). A study on the impacts of a U.S. program to increase energy efficiency of vehicles made by Small (2012) illustrates these issues. The author showed that a rise of $18.8 \%$ in fuel efficiency of new LDVs would reduce by $8.4 \%$ the total energy consumption of LDV fleet in 2030, but vehicle miles traveled (VMT) would be $1.9 \%$ higher than in 2010 and GHG emissions would decrease $1.6 \%$. Small and Dender (2007) estimated that efficiency gains in transports generated a rebound effect resulting in an increase between $20 \%$ to $25 \%$ in the amount of driving over the last one-third of 20th Century, whereas Herring and Roy (2007) estimated in $10 \%$ to $30 \%$ the rebound effect on the average vehicle miles traveled. With similar results, Morrow et al. (2010) concluded that efficiency growth is not sufficient to address GHG growth, as the economy and population are likely to growth over time, so measures to reduce VMT are needed as well.

In Brazil, the Federal Government launched the "Incentive to Technological Innovation and Densification of Motor Vehicles Production Chain" - Inovar-Auto (Federal Decree 7819/2012), which consists ofthe new automotive regime from the year 2013 to 2017 . This program conditions tax incentives to the achievement of the following goals: minimum shares of domestic inputs in the automotive production, R\&D and engineering investments, qualification of suppliers and increase of energy efficiency of manufactured vehicles. As a result, one expects to lower fuel consumption and emissions of GHG and pollutants.

To qualify for Inovar-Auto, the manufacturer must produce vehicles with an energy efficiency level at least $12.08 \%$ higher than that of vehicles produced in 2011. Once qualified, the manufacturer gains one percentage point reduction in the governmental tax on industrialized products (IPI), but should reach in 2017 at least $15.46 \%$ of energy efficiency gain compared to 2011, in order to hold such benefit. The reduction in IPI should reach 2 percentage points if the increase of energy efficiency achieves at least $18.84 \%$. The deadline of achieving the goals is 2017 (ABDI-MDIC, 2013). Until August 2013, forty companies were 
TTW GHG emissions from passenger transports

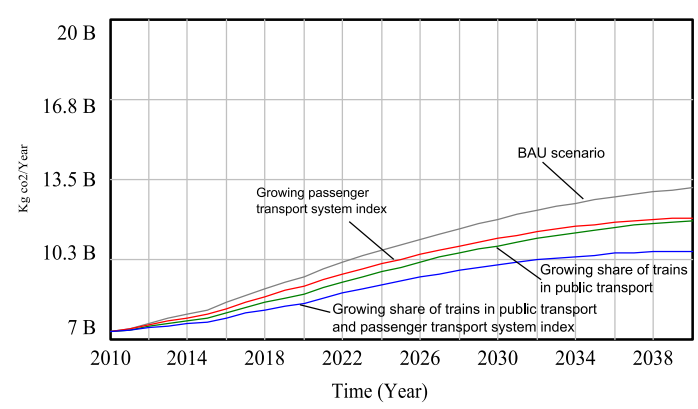

WTW GHG emissions from passenger transports

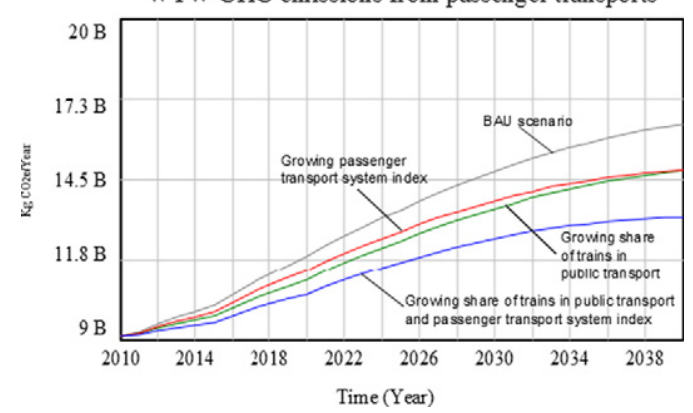

Fig. 1. GHG emissions from fuel consumption (TTW) and total (WTW), passenger transport only - various scenarios. Source: devised by the authors using ForFITS.

qualified for Inovar-Auto, with a total investment projected at $\mathrm{R} \$ 5.8$ billion until 2016, plus an addition of $\mathrm{R} \$ 2$ billion to invest in technology research, according to the Federal Government. Although estimates indicate that investments will be lower than the tax benefits obtained by companies, the total loss for the government with the IPI reduction would turn into fuel savings, estimated at $447 \mathrm{l}$ of gasoline per consumer per year from 2016 (around $\mathrm{R} \$ 1200$ per consumer per year), and the reduction of carbon emissions would be between 21.2 million and 41.5 million tons by 2017 (ABDI-MDIC, 2013; Dantas, 2013).

To test possible effects of policies oriented to improve fuel efficiency, ForFITS allows to change input parameters related to efficiency per type of vehicle. As previously mentioned, ForFITS' default values assume that current technologies of motor vehicles may be subject to improvements over time, in order to increase the efficiency of combustion engines. According to ForFITS' default values, the energy efficiency of light (passenger) and commercial light (freight) vehicles would be $10.8 \%$ higher in 2017 than in the base year; $12.3 \%$ higher in 2018; and 28.14\% higher in 2040. These assumptions are compatible with the minimum goal of $12.08 \%$ of the Inovar-Auto (with a one-year delay).

In order to verify the effects of improvement in energy efficiency of light and commercial light vehicles, the effects of the two other goals proposed by the Brazilian Program on GHG emissions were tested. Table 10 presents the hypotheses of these scenarios. The intermediate and maximum goal would be reached by 2017 and, from 2018 to 2040 , annual growth rates of energy efficiency would be equal to BAU scenario, resulting in a higher fuel efficiency at the end of simulation period.

The results are presented in Table 11. Indeed, an improvement in fuel efficiency of vehicles would promote reductions in energy consumption and, hence, in GHG emissions. These reductions are small, although as expected considering the results from other studies, as that of Small, 2012.

Total pkm in the scenarios with higher fuel efficiency is lower than in the BAU scenario, but it does not mean that there was no rebound effect. It was masked by a lower pkm of public transport. Actually, the pkm of private vehicles increased, induced by the wealth effect due to a lower fuel consumption of vehicles. This effect also reflects a small expansion in the stock of private vehicles. This rebound effect probably is underestimated in these scenarios, since the prices of vehicles were not adjusted to the new technological efficiency patterns (for

Table 10

Energy efficiency growth scenarios.

\begin{tabular}{|c|c|}
\hline Scenario & $\begin{array}{l}\text { Energy efficiency growth } \\
\text { compared to base year }\end{array}$ \\
\hline BAU (ForFITS' default values) & In 2018: $12.3 \%$ In 2040: $28.4 \%$ \\
\hline $\begin{array}{l}\text { Energy efficiency gain of } 15.46 \% \text { in } 2017 \\
\quad \text { (Inovar-Auto intermediate goal) }\end{array}$ & In $2017: 15.46 \%$ In $2040: 32.2 \%$ \\
\hline $\begin{array}{l}\text { Energy efficiency gain of } 18.84 \% \text { in } 2017 \\
\text { (Inovar-Auto maximum goal) }\end{array}$ & In $2017: 12.3 \%$ In 2040: $36.2 \%$ \\
\hline
\end{tabular}

simplification). Notwithstanding, the simulation results are consistent with the evidences that attest the contribution of the efficiency gains to effectively attenuate GHG emissions and air pollution. Even with such limitations, given the low magnitude of GHG reduction shown in the results, these scenarios confirm that efficiency gains are not enough to reduce total GHG emissions from transport sector because the growth rate of vehicles is higher than the rate of efficiency improvement. Therefore, efficiency gains should be combined with measures to reduce the rebound effect on the demand for travels in private vehicles (as those discussed in the previous subsections).

\subsection{Promoting the use of biofuels}

The use of ethanol as a fuel in Brazil was boosted in the 1970s by the National Alcohol Program (Proalcool), driven by the need to diversify fuel sources and reduce dependence on imported oil. In 2003, the Brazilian automobile industry started to produce the flex fuel vehicles, i.e., vehicles powered by gasoline and pure ethanol as well. The share of flex-fuel vehicles over the total sales of light vehicles in Brazil reached $88.5 \%$ in $2012,{ }^{16}$ driving the increase in the share of ethanol in the fuel market. In the São Paulo State, ethanol represented 57\% of fuel consumed by flex fuel vehicles in 2012 (CETESB, 2013).

The environmentally-friendly features of the ethanol industry also encouraged its development. In the combustion phase, as carbon emissions from the combustion of ethanol is a biogenic process, it does not count as GHG emissions (IPCC, 2006). Moreover, emissions from the combustion of ethanol are also free of some pollutants that are harmful to health, such as lead and sulfur, and emissions of carbon monoxide and particulate matter are significantly lower when compared to gasoline. On the production side, the volume of GHG emissions generated during the production of ethanol is half that of the production cycle of gasoline.

The ecological benefits of ethanol production has been under intense debate due to the risk of sugarcane cultivation stimulate deforestation and the replacement of food crops. But according to most recent studies, in 2005, the proportion of Brazilian territory devoted to sugarcane cultivation reached $0.9 \%$ of Brazil's total area (and sugarcane for ethanol, $0.5 \%$ ), while the whole agriculture occupied $8.5 \%$ of the Brazilian territory, half of this only with soil and corn (Neves et al., 2011). Since 1993, the expansion of the cultivation of sugarcane in the Center South of Brazil has taken place based mostly on preexisting units and with a minimal expansion of agricultural frontier (Macedo, 2005). Indeed, the growth of sugarcane production in São Paulo State occurred through the replacement of other crops and pastures. However, according to Kohlhepp (2010), the reduction of areas with other crops was compensated by a substantial growth of farming productivity. The rise of food prices in Brazil in last decades was due to other factors (i.e. increasing

\footnotetext{
16 According to the National Association of Vehicle Manufacturer (Anfavea).
} 
Table 11

Sensitivity of GHG emissions to fuel efficiency gains.

Source: devised by the authors using ForFITS.

\begin{tabular}{|c|c|c|c|c|c|}
\hline \multicolumn{6}{|l|}{ Efficiency gain reaching $15.46 \%$ in 2017} \\
\hline Variables & Unit & Base year & 2040 & Rate $2040 /$ base year & Variation 2040/BAU scenario \\
\hline Total pkm & Pkm, billion & 179 & 312 & 1,7 & $-2 \%$ \\
\hline Total energy used - passenger and freight modes & Toe, million & 6 & 13 & 2.2 & $-3 \%$ \\
\hline GHG emissions TTW - Total & $\mathrm{kg} \mathrm{CO}{ }_{2} \mathrm{e}$, billion & 14 & 13 & 2,2 & $-3 \%$ \\
\hline GHG emissions TTW - passenger modes only & & 7 & 30 & 2,2 & $-3 \%$ \\
\hline GHG emissions WTW - Total & & 17 & 13 & 1,7 & $-3 \%$ \\
\hline GHG emissions WTW - passenger modes only & & 9 & 37 & 2,2 & $-3 \%$ \\
\hline \multicolumn{6}{|l|}{ Efficiency gain reaching 18.84\% in 2017} \\
\hline Variables & Unit & Base year & 2040 & Rate 2040/Base year & Variation 2040/BAU scenario \\
\hline Total pkm & Pkm, billion & 179 & 312 & 1,7 & $-2 \%$ \\
\hline Total energy used - passenger and freight modes & Toe, million & 6 & 12 & 2.1 & $-5 \%$ \\
\hline GHG emissions TTW - Total & $\mathrm{kg} \mathrm{CO}{ }_{2} \mathrm{e}$, billion & 14 & 12 & 2,1 & $-4 \%$ \\
\hline GHG emissions TTW - passenger modes only & & 7 & 30 & 2,2 & $-6 \%$ \\
\hline GHG emissions WTW - Total & & 17 & 12 & 1,7 & $-4 \%$ \\
\hline GHG emissions WTW - passenger modes only & & 9 & 36 & 2,1 & $-6 \%$ \\
\hline
\end{tabular}

prices of commodities in the whole world) rather than reduction in the supply of food products.

Moreover, the environmental impact of sugar cane cultivation is relatively low. Sugarcane culture develops easily in poor soil, without irrigation in most cases; provides a very low soil loss by erosion and contributes to soil recovery due to its biological characteristics (Macedo, 2005). It is worth mention that promising results of researches on the production of second-generation ethanol suggest an increasing productivity of energy use of sugarcane in the future, hence reducing GHG emissions of each energy unit of sugarcane ethanol (Raele et al., 2014).

The consumers' choice between ethanol and gasoline depends on the relative price and performance of these fuels. Consumers tend to opt for ethanol when its price corresponds to less than two thirds of the price of gasoline, which is also the approximate proportion of energy contained in one amount of ethanol compared to the same amount of gasoline (CETESB, 2013).

Assuming that the relationship between the prices of gasoline and ethanol remains stable and that the market share of ethanol continues to increase, we conducted two tests with variations in the share of the use of ethanol. In the first test, the use of ethanol was set as growing until reaching $50 \%$ of the fuel market for vehicles and motorcycles in 2040. In the second test, this share reaches $100 \%$ at the end of simulation period. ${ }^{17}$ In both simulations, we assume that by the end of the period all gasoline-powered and ethanol-powered light and commercial vehicles and motorcycles would be replaced by an equivalent with a flex motor that can be fueled with both fuels. Table 12 presents the results.

TTW GHG emissions would decrease $11 \%$ over total (or $19 \%$ over emissions from passenger modes only) in the scenario where ethanol has a market share of $50 \%$, and $33 \%$ (or $58 \%$ over emissions from passenger modes) with the biofuel having $100 \%$ of share in passenger private vehicles. In the latter scenario, GHG emissions in 2040 from passenger modes are lower than in the base year. In turn, the WTW reductions in carbon emissions were slightly lower because the emissions in the production phase of ethanol are higher, which slightly attenuate the reduction in WTW GHG emissions.

In turn, GHG emissions from biodiesel concern the passenger bus mode and the freight transport. Emission of pollutants from

\footnotetext{
17 These hypotheses are compatible with the scenarios of energy matrix presented by EPE (2014) and São Paulo (2011). From the projections of demand for gasoline C and ethanol made by the Public Company of Energetic Planning (EPE - Empresa de Planejamento Energético), one can estimate that the share of ethanol in 2040 would reach 38\% (EPE, 2014). In turn, to project the State's energy matrix in 2035, one of the State Secretary of Energy of São Paulo's assumption was that $90 \%$ of passenger light and commercial light vehicles and motorcycles would be fueled with ethanol and $10 \%$, with gasoline C; electric cars would be just 3\% of vehicles fleet in São Paulo State in 2035 São Paulo (2011)).
}

consumption of biodiesel is lower, but GHG volumes vary as a function of the raw material employed to produce it. According to Carvalho (2012), diesel derived from soybean emits less GHG than conventional diesel in the combustion phase, but emits more in its production phase. On the other hand, the production of soybean diesel generates co-products that are also responsible for emitting GHG. Since part of the emissions from soybean diesel ate attributable to co-products, the GHG emission factors of this biodiesel tend to fall in a proportion ranging between $40 \%$ (with the appropriation by the economic value of the co-products) and 67\% (with the appropriation by the mass of the coproducts, according to Carvalho, 2012). Differences in volumes of GHG emissions in production are due to the characteristics of each culture, such as the intensity of fertilization (which is a source of carbon emissions) and the land productivity. Large-scale and technology-intensive soybean production is widely established in Brazil (Rovere et al., 2009). However, to meet the demand created by the new legally-fixed composition of diesel (between $5 \%$ and $7 \%$ of biodiesel), biodiesel production would have to triplicate until 2050 (EPE, 2014).

In Brazil, $77 \%$ of the biodiesel consumed in 2014 came from soybeans (ANP, 2015), and the legally fixed proportion of biodiesel in the commercial diesel blend is 7\% since November 2014 (Federal Law 13.033/ 2014). To simulate a scenario with biodiesel, we assume that all biodiesel is made from this grain and all diesel-powered vehicles use B10, a blend of $90 \%$ common diesel and $10 \%$ of biodiesel from soybean. ${ }^{18}$

Table 13 shows a scenario with the use of B10 reaching $100 \%$ in 2040 considering the co-products appropriating $40 \%$ of GHG emissions. The results indicate that the GHG emissions avoided in biodiesel consumption would be partially offset by a higher level of GHG emissions during its production.

Scenarios with the use of biofuels were also built by UNECE (2013). For example, increasing the use of biofuels to $20 \%$ of the main fuel blends would decrease GHG emissions relative to reference scenario between 15\% (Chile) and 16.7\% (Montenegro). In turn, World Bank (2011) simulated a scenario where flex-fuel vehicles reach $92 \%$ of Brazilian fleet and ethanol reaches $79 \%$ of fuel share among flex-fuel fleet. In such scenario, GHG emissions from Brazilian total urban passenger transport would be $26.4 \%$ lower, and the emissions from total transport sector would be $13.6 \%$ lower in 2030 compared to reference scenario. ${ }^{19}$

The continuous allocation of resources for research projects and development (R\&D) in biofuels and vehicles powered by clean energy would be essential to incentivize the technological development of

\footnotetext{
18 To project the future energy matrix, EPE (2014) and São Paulo (2011) assumes the adoption of B10, a diesel blend with $10 \%$ of soybean diesel.

${ }_{19}$ This rate was estimated by authors with World Bank simulation results for Brazilian aggregated urban areas.
} 
Table 12

Senstivity of GHG emissions to an increase of the use of ethanol.

Source: devised by the authors using ForFITS.

\begin{tabular}{|c|c|c|c|c|c|}
\hline \multicolumn{6}{|l|}{ Increase of use of ethanol to $50 \%$ in 2040} \\
\hline Variables & Unit & Base year & 2040 & Rate 2040/Base year & Variation 2040/BAU scenario \\
\hline GHG emissions TTW - Total & $\mathrm{kg} \mathrm{CO} 2 \mathrm{e}$, billion & 14 & 27 & 2,0 & $-12 \%$ \\
\hline GHG emissions TTW - passenger modes only & & 7 & 10 & 1,4 & $-21 \%$ \\
\hline GHG emissions WTW - Total & & 17 & 34 & 2,0 & $-11 \%$ \\
\hline GHG emissions WTW - passenger modes only & & 9 & 13 & 1,5 & $-19 \%$ \\
\hline \multicolumn{6}{|l|}{ Increase of use of ethanol to $100 \%$ in 2040} \\
\hline GHG emissions TTW - Total & $\mathrm{kg} \mathrm{CO} 2 \mathrm{e}$, billion & 14 & 21 & 1,5 & $-33 \%$ \\
\hline GHG emissions TTW - passenger modes only & & 7 & 6 & 0,8 & $-58 \%$ \\
\hline GHG emissions WTW - Total & & 17 & 26 & 1,6 & $-31 \%$ \\
\hline GHG emissions WTW - passenger modes only & & 9 & 8 & 0,9 & $-52 \%$ \\
\hline
\end{tabular}

Table 13

GHG emissions with B20 share reaching 100\% in 2040.

Source: devised by the authors using ForFITS.

\begin{tabular}{|c|c|c|c|c|c|}
\hline \multicolumn{6}{|l|}{ Increase of use of B20 to $100 \%$ in 2040} \\
\hline Variables & Unit & Base year & 2040 & Rate 2040/Base year & Variation 2040/BAU scenario \\
\hline GHG emissions TTW - Total & $\mathrm{kg} \mathrm{CO}_{2} \mathrm{e}$, billion & 14 & 29 & 2,1 & $-6 \%$ \\
\hline GHG emissions TTW - passenger modes only & & 7 & 13 & 1,7 & $-4 \%$ \\
\hline GHG emissions WTW - Total & & 17 & 37 & 2,2 & $-2 \%$ \\
\hline GHG emissions WTW - passenger modes only & & 9 & 16 & 1,8 & $-1 \%$ \\
\hline
\end{tabular}

engines powered by biofuels with higher energy efficiency, as well as the productivity growth of biofuel production. For example, orientating technological research to produce biodiesel biodiesel from other sources (Rovere et al., 2009). Production and consumption of palm diesel would generate only $34 \%$ of GHG emissions obtained using regular diesel. Using such biodiesel in the B10 blend would reduce total emissions of this type of fuel. Nevertheless, the production of biodiesel from palm is still too low (it accounted for less than $1 \%$ of total biodiesel demanded in 2014, according to ANP, 2015). Therefore, an evaluation of the technical, economic and ecological feasibility of biodiesel from alternative sources to increase the productivity of production and the marketshare of less polluting types of biodiesel is required.

Exporting Brazilian ethanol technology would also contribute to consolidate ethanol in the international market (Vieira et al., 2007). In some Brazilian public administrations, fuelling their fleets of vehicles with biofuels is mandatory by law. Tax incentives could be granted by the three levels of government (federal, state, local) for the production of biofuels, as well as the reduction or elimination of subsidies on fossil fuels and financing for biomass producers. Governmental policies are also needed for further developments in ethanol production: according to Raele et al. (2014), policies to incentive production through subsidies are as important for the development of the second generation ethanol as the policies to stimulate its technological development.

Furthermore, the implementation of a clear and stable pricing policy is imperative to ensure the stability in the relationship between fuel prices and, then, to boost consumption of biofuels. This policy should include deadlines for incentives and be implemented concurrently with the application of technological and regulatory measures to consolidate the biofuel industry and market. It should also be continuous and have clear rules so as not to harm the sectors involved. Recently, Brazilian Federal Government used mechanisms to postpone the adjustment of the price of gasoline to curb the rise of general price inflation in the country. This measure has been extremely harmful to the ethanol industry, making it economically less advantageous to the consumer and resulting in the current ethanol industry crisis leading to the insolvency of numerous sugarcane mills (Daltro, 2013; Turtelli, 2014).

Investment in biofuel also poses other risks. According to OECD/IEA (2014), in Brazil, the cost of labor and land prices have experienced relevant increases in recent years, which may raise ethanol's production costs. Moreover, recent decrease of the oil price may affect the relationship between the prices of fuels unfavorably for ethanol and biodiesel. In the case of biodiesel, the Federal Government has launched National Program of Production and Use of Biodiesel $\left(\mathrm{PNPB}^{20}\right)$ in 2004 to promote the development of other oilseed cultures to produce biodiesel by providing reduced tax rates, lower loan costs and subsidies to cover differences between production costs of conventional diesel and biodiesel. The program has also created with a social development goal through the incentives to small farmers' production (IPEA, 2012; Rovere et al., 2009). However, the incentives from PNPB have been insufficient to compensate the high production costs, high seasonality, low productivity of the small farmers and the huge economic advantages of the soybean diesel (Toledo, 2012).

\section{Integrating policies}

In the last section, we evaluated several policy scenarios, taking policies individually. Assuming that our scenarios correctly reflect the magnitude of the potential impact of each policy, we verify that the most effective to reduce GHG emissions would be the dissemination of use of ethanol. With the share of this biofuel reaching $50 \%$ in 2040 , GHG emissions in this scenario are lower than those among the selected policy scenario at the end of the simulation period. Among all scenarios presented in this paper, that with growth of use of ethanol until reaching $100 \%$ of fuel share between ethanol and gasoline $C$ is the only one where the TTW and WTW GHG emissions in 2040 is lower than in the base year. Nevertheless, it is far from reaching the goal of $30 \%$ reduction in ten years as stated by local public administration (as mentioned in Section 2).

To see the effects of the deployment of some of these measures concomitantly, we grouped them into three sets and simulated their effects. The results are presented in Fig. 2 and Table 14.

The Set of Policies I includes technology-related policies, i.e. incentives to increase energy efficiency (the most optimistic hypothesis of a

\footnotetext{
${ }^{20}$ Acronym in Portuguese for "Programa Nacional de Produção e Uso de Biodiesel".
} 

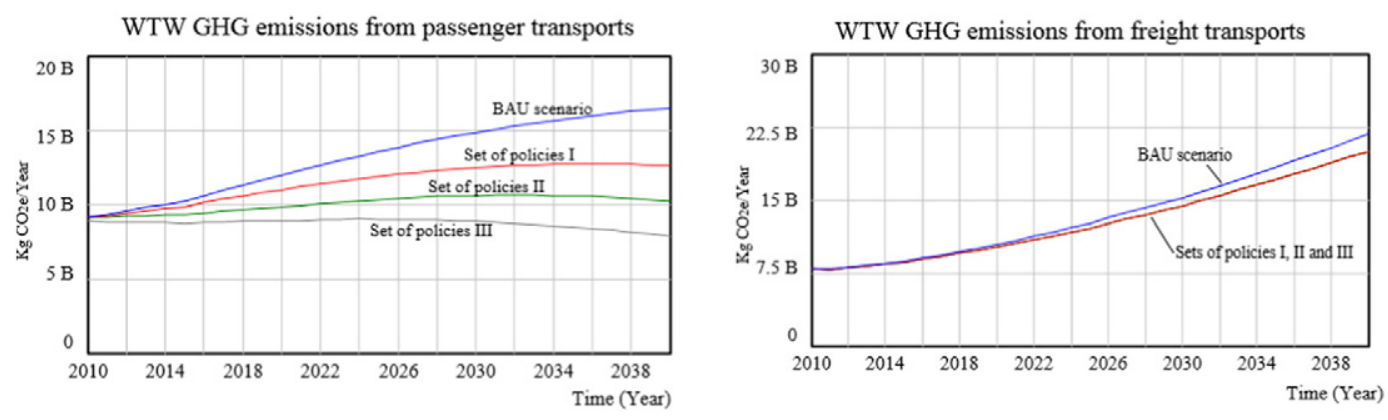

Fig. 2. WTW GEE emissions from passenger transports - BAU scenario and scenarios with implementation of sets of policies.

Table 14

Simulation results for scenarios with sets of policies.

\begin{tabular}{|c|c|c|c|c|c|}
\hline Variables & Unit & Base year & 2040 & Rate 2040/Base year & Variation 2040/BAU scenario \\
\hline Total pkm & Pkm, billion & 179 & 312 & 1.7 & $-2 \%$ \\
\hline Total energy used - passenger and freight modes & Toe, million & 6 & 12 & 2,1 & $-6 \%$ \\
\hline GHG emissions TTW - Total & $\mathrm{kg} \mathrm{CO}{ }_{2} \mathrm{e}$, billion & 14 & 26 & 1.9 & $-15 \%$ \\
\hline GHG emissions TTW - passenger modes only & & 7 & 10 & 1.4 & $-25 \%$ \\
\hline GHG emissions WTW - Total & & 17 & 33 & 1.9 & $-14 \%$ \\
\hline GHG emissions WTW - passenger modes only & & 9 & 13 & 1.4 & $-23 \%$ \\
\hline \multicolumn{6}{|c|}{ Set of policies II: set of policies I plus policies to public transport - growth of share of railroads in pkm and improvements of urban transport system management } \\
\hline Variables & Unit & Base year & 2040 & Rate 2040/Base year & Variation 2040/BAU scenario \\
\hline Total pkm & Pkm, billion & 179 & 297 & 1.7 & $-7 \%$ \\
\hline Total energy used - passenger and freight modes & Toe, million & 6 & 12 & 2.0 & $-12 \%$ \\
\hline GHG emissions TTW - Total & $\mathrm{kg} \mathrm{CO}{ }_{2} \mathrm{e}$, billion & 14 & 24 & 1.8 & $-22 \%$ \\
\hline GHG emissions TTW - passenger modes only & & 7 & 8 & 1.1 & $-40 \%$ \\
\hline GHG emissions WTW - Total & & 17 & 30 & 1.8 & $-21 \%$ \\
\hline GHG emissions WTW - passenger modes only & & 9 & 10 & 1.1 & $-37 \%$ \\
\hline \multicolumn{6}{|c|}{ Set of policies III: set of policies II plus incentives to telework and to shared private transport } \\
\hline Variables & Unit & Base year & 2040 & Rate 2040/Base year & Variation 2040/BAU scenario \\
\hline Total pkm & Pkm, billion & 190 & 232 & 1.2 & $-27 \%$ \\
\hline Total energy used - passenger and freight modes & Toe, million & 6 & 10 & 1.8 & $-23 \%$ \\
\hline GHG emissions TTW - Total & $\mathrm{kg} \mathrm{CO}{ }_{2} \mathrm{e}$, billion & 14 & 23 & 1.7 & $-27 \%$ \\
\hline GHG emissions TTW - passenger modes only & & 7 & 6 & 0.9 & $-54 \%$ \\
\hline GHG emissions WTW - Total & & 17 & 28 & 1.7 & $-27 \%$ \\
\hline GHG emissions WTW - passenger modes only & & 9 & 8 & 0.9 & $-52 \%$ \\
\hline
\end{tabular}

gain of $18.84 \%$ ) and to stimulate the use of ethanol (reaching the share of 50\%). Among the selected policies of the present study, these policies may be the most feasible and with a background history that allows to more realistically estimate its potential impacts. Incentives to increase energy efficiency are already in progress in Brazil, through governmental programs such as Inovar-Auto (mentioned in Subsection 4.4), but more discussion to improve the effectiveness of these incentives is needed. In turn, ethanol has become an important component of Brazilian energy matrix. In order to improve the advantages of ethanol and the strength of Brazilian sugar and alcohol sector, the policies to improve technologies of ethanol production and fuel prices policies need predictability and continuity, although this orientation has not been followed in the last years by the Brazilian government (as commented in Subsection 4.5).

The Set of Policies II includes, besides the technological policies of the first Set, improvements in the quality of public transport (which would imply in an increase in the passenger transport system index) and stimulus to increase participation of the subway-railroad on public transport. The estimates of its potential to reduce GHG emissions reinforce the conclusion that improving the public transport and incentivizing its use instead of private one is imperative to local strategies to mitigate GHG emissions.

Lastly, the Set of Policies III includes Sets I and II plus measures aiming to reduce the intensity of use of passenger transport, i.e. incentives to teleworking and to shared private transport. These last policies presented the lowest impacts in the simulated scenarios. According to those studies mentioned in Subsections 4.1 and 4.2, the magnitude of the impact of these policies are uncertain and limited by several factors, such as the actual feasibility of implementation and managerial, social and economic cost-benefit issues that are difficult to evaluate.

When observing the WTW GHG emissions, with the implementation of the Set I, the total emissions decrease around $14 \%$ and from passenger modes only, 23\% in 2040 compared to BAU Scenario. In turn, the other mixes would propitiate, in 2040, WTW total GHG emission between $21 \%$ (Set II) and 27\% (Set III) lower than in BAU scenario. Considering passenger modes only, WTW GHG emissions would be $37 \%$ (Set II) and $52 \%$ (Set III) lower in the last year than passenger modes emissions observed in the BAU scenario.

Overall, these simulations unveil synergies among selected mitigation measures in São Paulo City's transport system, which means that the goals of reducing GHG emissions may become more feasible with the adoption of policy mixes. The more diversified these mixes, the greater is the impact over GHG emissions. Considering the three policy mix scenarios above, the only set of policies that would result in a GHG emissions level from passenger transport in 2040 lower than that of the base year is the Set of Policies III, which covers the most diversified group of policies. Nevertheless, if considering total emissions (from passenger and freight modes), none of policy packages would result in a reduction of GHG emissions below the base year level. Therefore, combined policies for passenger transport show a very high potential impact, but more policies should complement them, especially those that affect freight transport. 


\section{Conclusions and recommendations}

This article is the first to present a comprehensive and integrated assessment of the main proposals of low carbon development strategies for São Paulo City's transport system. This assessment was supported by a dynamic simulation model adjusted to São Paulo's socioeconomic aspects and transport features, which enabled the building of policy scenarios. Each scenario was evaluated taking into account institutional aspects, benefits and risks associated to the potential impacts. In addition, three scenarios with different mixes of policies were tested and analyzed. All these procedures lead to the conclusion that all selected measures have complementary social and economic benefits, besides those directly associated with the reduction of GHG emissions from transport.

Policies that could negatively affect the average distance traveled per vehicle might contribute to a higher quality of life for São Paulo's population, but in terms of GHG emissions, their impacts would be more limited, due to the difficulties to promote further diffusion of teleworking and of private transport sharing. Considering a growth of $20 \%$ of teleworkers from 2010 to 2040, the simulated impact on GHG emissions was low $(-1 \%$ in overall transport sector and $-3 \%$ in the passenger modes). Such low levels of reduction were also pointed by Kitou and Horvath (2008), suggesting that teleworking may stimulate other travels not related to work and faces organizational and managerial difficulties to its further adoption by companies and workers. Moreover, this growth might be higher, but as also suggested by Ipsos (2011), Brazil has already reached a high proportion of teleworkers among total workers compared to the world's average.

There is still no consensus in the literature about the effects of policies to incentive carpooling, which could have positive (for example, Fontes et al., 2014) or even negative impacts (for example, Shewmake, 2012). Supposing there are effective measures able to rise the average occupancy per private vehicle in São Paulo to two passengers per vehicle (against 1.4 in 2011), the effect on GHG emissions would be moderate ( $-4 \%$ over total or $-8 \%$ over GHG emissions from passenger modes). Nevertheless, this supposition seems too optimistic when the statistics show a downward trend in the already low average occupancy per vehicle in richer countries. As a big city of a medium-income country, São Paulo has a potential to increase its fleet, reducing the vehicle occupancy and, thus, the potential impacts of measures to incentivizing private shared transport aiming the reduction of GHG emissions.

Policies to improve public transport are feasible and have a high potential to reduce GHG emissions. The pkm share of public transport is already high in São Paulo City, but there is still a high number of users that could shift from private to public transport. Besides being crucial to the population's well-being and quality of life, the improvement of the quality of public transport is impactful in terms of GHG emissions. As most of GHG emissions from public transport is due to buses (which are powered by diesel), an additional reduction in these emissions could be reached with an expansion of the subway system and of its share in public transport, result that is also highlighted by the World Bank (2011). The main concern lies in the managerial and financial resources to implement measures to enlarge the capacity of the urban rails system (subways and intercity trains) and to improve the quality of the services (mainly management issues). Public transport is a local issue, but needs additional support from Federal and State governments, given the massive volume of financial resources needed to implement this policy.

With respect to biofuels, the sugarcane ethanol is part of a consolidated agro-industrial chain and the potential to increase the production is high yet. The broader emissions reduction compared to the BAU scenario occurred with a higher share of ethanol among light and commercial vehicles and motorcycles. Higher shares for ethanol could be achieved with technological and economic stimulus to the ethanol industry, such as price policies and financing research and development, whose consequences would not be restricted to São Paulo City.
However, recent economic constraints and the Brazilian policies for the fuel price in the last years pose major challenges to the economic viability of these industries. The same applies to biodiesel from soy and other sources (for example, palm), with additional challenges, such as environmental issues related to the soybean culture (the main current source of biodiesel in Brazil) and, in the case of more environmentally friendly alternative sources of biodiesel, their economic viability in the face of the large-scale production of the soybean diesel.

Overall, the most effective strategy combines the massive adoption of ethanol with a shift to public transport. One should also observe the need to integrate the impact analysis with other institutional aspects, benefits and risks. For example, the adoption of biofuels is subject to actions of incentives to its production, which is the competence of the Brazilian Federal Government, as well as the adoption of more energyefficient vehicles. In turn, the management of public transport is a local government assignment, although the high investment costs often requires the participation of regional and national government. Reduction of GHG emissions would not be the only benefits of these integrated actions. A wider use of ethanol reinforces the diversification of the Brazilian energy matrix, reducing dependence on fossil fuels and diversifying national industry. A wider use of public transport reduces energy consumption and also the household expenses. All measures together would reduce the transit time of the citizens and improve the quality of life in many other ways (more free time, spending less on transport, less pollution). However, the success of these measures would depend on well-organized and coordinated actions among the various stakeholders, overcoming any political barriers or lack of planning, which characterize much of the Brazilian policy actions.

Based on these results, the main recommendation for the decision makers would be to concentrate efforts on those measures included in the Sets of Policies I and II. This means that policymakers should improve the measures that represent a continuation of policies that are already being implemented. In this sense, the encouragement of the use of ethanol still have much room to expand, as well the fuel efficiency growth, the improvements in public transport and the expansion of passenger rail system. In turn, the measures contained in the Set of Policies III need more study to attest their effectiveness to the reduction of GHG emissions and their contribution to the population's welfare. Although these scenarios with a blend of policies achieved the best results in reducing emissions from passenger modes, they were not enough to achieve the reduction in GHG emissions (including passenger and freight modes) stated by the São Paulo City. It means that a careful analysis of the intensity of policies' effects and an evaluation of possible additional measures (other than those selected in this study) are mandatory.

In order to proceed, new rounds of policy evaluation are highly recommended, including other policies. The transport policies selected for this analysis present passenger transport as target, with the exception of the policy to promote the use of biofuel, which also affects the freight modes. This factor explains why the impacts of the select policies on GHG emissions from passenger transport is substantial, though the impacts on the total emissions of passenger and freight transports is lower. Such results may indicate some directions to policy prioritization and the importance to discuss policies related, for example, to freight transport. This would include, besides stimulus to biodiesel, the need to further develop other modes, such as freight railroads and waterways. Congestion pricing to reduce the average distance traveled per vehicle (if it would be considered feasible for São Paulo City) and other policies to incentivize technological shift to electric car may also be impactful in the long run.

These discussions require undoubtedly a greater coordination between local, state and federal public administrations. For example, coordinating policies that involve changes in existing standards (such as energetic efficiency), price policy, tax incentives and subsidies, resource transfers and funding. There is also need of consistency and continuity of public policies, especially the stimulus to the use of biofuels, which 
come under federal competence, and improvement of the public transport system.

Despite some limitations regarding the dynamic simulation model used in this study (ForFITS), such as the difficulty to compare its results with estimates from GHG inventories, or its inadequacy for some kinds of policies, it is a useful tool to foster discussion and learning about the likely effects of GHG mitigation policies and possible interactions and comparisons among them. In addition, it helps to demonstrate how important the concomitant actions at all government levels (local, state or federal) are for a successful low carbon development strategy.

The analysis developed in this study is intended to be just the initial step in establishing which policies are feasible and useful for developing a low carbon strategy suitable for a megacity like São Paulo. Future steps should introduce other policies in the analysis of further reductions in GHG emissions, according to the results of the first round of policy evaluation presented in this paper. As well, the quantification of the costs of each policy mix would be another important step to develop: it would enable to make a cost-benefit analysis and provide the decisionmaking process with other elements for planning and implementing the best policies for the local transport system development. In addition, it should involve coordination among institutions and federative entities to allow the continuity of policy cycle, assuring periodical planning, execution, assessment and adjustments of São Paulo's low carbon development strategies for its transport sector.

\section{Acknowledgements}

This study is based on a result of the ECLAC's Project "Cambio Climático: Oportunidades Para Sendas De Desarrollo Baja En Carbono", funded by the Program of Cooperation ECLAC-BMZ/GIZ (GER/12/001). The opinions expressed in this work are the sole responsibility of the authors and do not necessarily reflect the views of the Organizations. We are grateful to the anonymous referees for the comments that substantially improved the paper and the support provided by the Forfits team of the UNECE.

\section{References}

ABDI-MDIC, 2013. Brasil Maior: Executive Balance - 2 years (in Portuguese).

Alcott, B., 2005. Jevons paradox. Ecol. Econ. 54, 9-21.

Andrejszk, T., Torok, A., Molnar, E., 2014a. The long-term forecast of land passenger transport related $\mathrm{CO}_{2}$ emission and energy use in Hungary. Int. J. Traffic Transp. Eng. 4 386-396.

Andrejszk, T., Gangonells, M., Molnar, E., Török, Á., 2014b. ForFITS: a new help in transport decision making for a sustainable future. Period. Polytech. Transp. Eng. 42 (2), 119-124.

ANP, 2015. Oil, Natural Gas and Biofuels Statistical Yearbook. National Agency of Petroleum, Natural Gas and Biofuels - ANP, Rio de Janeiro.

BLS, 2015. American time use survey - 2014 results. Access in 20 de 12 de 2015, available at Bureau of Labor Statistics - U.S. Department of Labor. http://www.bls.gov/news. release/atus.nr0.htm.

Caltrans, 2006. Modeling the Effectiveness of High Occupancy Vehicle (HOV) Lanes at Improving Air Quality. California Department of Transportation.

Carvalho, P.T., 2012. Balanço de Emissões de Gases de Efeito Estufa de Biodiesel Produzido a Partir de Soja e Dendê no Brasil (MSc Dissertation) UFRJ/COPPE, Rio de Janeiro.

Carvalho, C.S., 2014. Senda de desarrollo urbano bajo en carbono para transitar hacia una economía verde - São Paulo. Proyecto ger/12/001 "Cambio climático: oportunidades para sendas de desarrollo baja en carbono". CEPAL, División Desarrollo Sostenible y Asentamientos Humanos.

CETESB, 2011a. $1^{\circ}$ Inventário de Emissões Antrópicas de Gases de Efeito Estufa Diretos e Indiretos do Estado de São Paulo (2a. edição). CETESB.

CETESB, 2011b. Plano de Controle de Poluição Veicular do Estado de São Paulo 20112013.

CETESB, 2012. Relatório de Emissões Veiculares no Estado de São Paulo 2011.

CETESB, 2013. Relatório de Emissões Veiculares no Estado de São Paulo 2012.

CET-SP, 2014. CET promove Semana de Carona Solidária para marcar o Dia Mundial Sem Carro. Access in Dec. 23, 2014, available at Companhia de Engenharia de Tráfego de São Paulo - CET-SP. www.cetsp.com.br.

Choo, S., Mokhtarian, P.L., Salomon, I., 2005. Does telecommuting reduce vehicle-miles traveled? An aggregate time series analysis for the U.S. Transportation. 32, 37-64.

Commander, S., Nikoloski, Z., Vagliasindi, M., 2015. Estimating the size of external effects of energy subsidies in transport and agriculture. Policy Research Working Paper, 7227. World Bank (April de).

Daltro, A.L., 2013. Golpe na Energia Verde. Veja 95-96 (Sep. 18, 2013).
Dantas, I., 2013. Novo regime automotivo deve gerar investimentos de R\$ 5,5 bi até 2017. O Estado de São Paulo, Jan. 11, 2013. Access Jun. 20, 2014 available at: http:// economia.estadao.com.br.

Edwards, R., et al., 2006. Well-To-Wheels Analysis of Future Automotive Fuels and Powertrains in the European Context - TANK-To-WHEELS Report; Version 2b. JRC IES/Concawe/EUCAR

Ekos-Geoklock, 2013. Inventário de emissões e remoções antrópicas de gases de efeito estufa do Município de São Paulo de 2003 a 2009 com atualização para 2010 e 2011 nos setores Energia e Resíduos. ANTP, São Paulo.

EMPLASA, 2006. Pesquisa de origem e destino dos transportes rodoviários e aéreos do Estado de São Paulo Access in 25 de 02 de 2014, available at http://www.emplasa. sp.gov.br.

EPE, 2014. Energy Demand. Energy Research Company - EPE, Ministry of Mines and Energy, Rio de Janeiro.

Fiorello, D., Fermia, F., Bielanskaa, D., 2010. The ASTRA model for strategic assessment of transport policies. Syst. Dyn. Rev. 26 (3), 283-290.

Fong, W.-K., Matsumoto, H., Lun, Y.-F., 2009. Application of system dynamics model as decision making tool in urban planning process toward stabilizing carbon dioxide emissions from cities. Build. Environ. 44, 1528-1537.

Fontes, T., Fernandes, P., Rodrigues, H., Bandeira, J.M., Pereira, S.R., Khattak, A.J., et al., 2014. Are HOV/eco-lanes a sustainable option to reducing emissions in a mediumsized European city? Transp. Res. A 63, 93-106.

Herring, H., Roy, R., 2007. Technological innovation, energy efficient design and the rebound effect. Technovation 27 (2007), 194-203.

IPCC, 2006. In: Programme, N.G.G.I., Eggleston, H.S., Buendia, L., Miwa, K., Ngara, T., Tanabe, K. (Eds.), 2006 IPCC Guidelines for National Greenhouse Gas Inventories. IGES, Japan.

IPEA, 2012. Biodiesel no Brasil: desafios das políticas públicas para a dinamização da produção. Comunicados IPEA (137). IPEA.

Ipsos, 2011. Telecommuting: citizens in 24 countries assess working remotely for a Total global perspective. Access in Jan 10, 2015, available at ipsos global @dvisor:. http:// www.ipsos-na.com/download/pr.aspx?id=11327.

Jackson, T., 2009. Prosperity without Growth: Economics for a Finite Planet. Earthscan, London.

Kitou, E., Horvath, A., 2008. External air pollution costs of telework. Int. J. Life Cycle Assess. 13 (1), 155-165.

Kohlhepp, G. 2010. Análise da situação da produção de etanol e biodiesel no Brasil. Estud. Avançados 24 (68), 223-253 Retrieved January 05, 2015, from http://www.scielo.br/ scielo.php?script $=$ sci_arttext\&pid $=$ S0103-40142010000100017\&lng $=$ en\&tlng $=$ pt.

Kwon, J., Varaiya, P., 2008. Effectiveness of California's high occupancy vehicle (HOV) system. Transp. Res. C 16, 98-115.

Li, L., Hoffeman, R., McInnis, B., Paix, M.J., Li, X., 2012. Impacts of alternative vehicle fue policies on Canadian energy demand and emissions. Transp. Policy 21 (2012), 92-100.

Lister, K., Harnish, T., 2011. The State of Telework in the U.S.: How Individuals, Business, and Government Benefit. Telework Research Network.

Liu, X., Ma, S., Tian, J., Jia, N., Li, G., 2015. A system dynamics approach to scenario analysis for urban passenger transport energy consumption and $\mathrm{CO}_{2}$ emissions: a case study of Beijing. Energ Policy 85 (2015), 253-270.

Macedo, I.D., 2005. In: Macedo, I.D. (Ed.), A Energia da Cana-de-Açúcar - Doze estudos sobre a agroindústria da cana-de-açúcar no Brasil e a sua sustentabilidade. Berlendis \& Vertecchia: UNICA.

Mateyka, P.J., Rapino, M.A., Landivar, L.C., 2012. Home-Based Workers in the United States: 2010 - Household Economic Studies. U.S. Census Bureau.

MCT, 2013. Estimativas anuais de emissões de gases de efeito estufa no Brasil. Ministry of Science, Technology and Innovation, Brasília.

MDIC, 2012. Decreto estabelece as regras do Inovar-Auto, novo regime automotivo brasileiro. MDIC, Out. 04, 2012. Access in Apr 21, 2014 available at www. brasilmaior.mdic.gov.br.

METRO, 2012a. Sustainability Report 2012. Company of São Paulo's Metropolitan METRO, SP.

METRO, 2012b. Origin-Destination Survey (OD) 2012. São Paulo Metropolitan Company Metrô.

MMA, 2011. I Inventário Nacional de Emissões Atmosféricas por Veículos Automotores Rodoviários. MMA - Ministério do Meio Ambiente.

Morrow, W.R., Gallagher, K.S., Collantes, G., Lee, H., 2010. Analysis of policies to reduce oil consumption and greenhouse-gas emissions from the US transportation sector. Energ Policy 2010, 1305-1320.

Musango, J.K., Brent, A.C., Bassi, A.M., 2014. Modelling the transition towards a green economy in South Africa. Tech. Forecasting Soc. Chang. 87, 257-273.

Neves, M.F., Pinto, M.J., Conejero, M.A., Trombin, V.G., 2011. Food and Fuel: The Example of Brazil. Wageningen Academic Publishers, Wageningen.

OECD/IEA, 2014. Medium-Term Oil Market Report. IEA Publishing, Paris.

Office of National Statistics, 2014. Characteristics of home workers, 2014. Access in Nov 01, 2015, available at Office of National Statistics. http://www.ons.gov.uk/ons/ dcp171776_365592.pdf (June de).

OPM, 2013. 2013 Status of Telework in the Federal Government - Report to the Congress. United States Office of Personnel Management - OPM.

Pfaffenbichler, P., Embergera, G., Shepherdb, S., 2010. A system dynamics approach to land use transport interaction modelling: the strategic model MARS and its application. Syst. Dyn. Rev. 26 (3), 262-282.

Raele, R., Boaventura, J.G., Fischmann, A.A., Sarturi, G., 2014. Scenarios for the second generation ethanol in Brazil. Tech. Forecasting Soc. Chang. 87, 205-223.

Rodríguez, R.S., 2013. Respuestas urbanas al cambio climático en America Latina Comisión Económica para América Latina y el Caribe, Santiago.

Rovere, E.L., Avzaradel, A.C., Monteiro, J.M., 2009. Potential synergy between adaptation and mitigation strategies: production of vegetable oils and biodiesel in northeastern Brazil. Clim. Res. 40, 233-239. 
Sabounchi, N.S., Triantis, K.P., Sarangi, S., Liu, S., 2014. Dynamic simulation modeling and policy analysis of an area-based congestion pricing scheme for a transportation socioeconomic system. Transp. Res. A 59, 357-383.

Samaniego, J., Jordán, R., Ruiz-Tagle, M.T., 2013. Estrategias de desarrollo bajo en carbono en megaciudades de América Latina. CEPAL.

São Paulo, 2011. Guidelines for the Action Plan of the City of São Paulo for Mitigation and Adaptation to Climate Change. São Paulo City Hall.

Shewmake, S., 2012. Can carpooling clear the road and clean the air? Evidence from the literature on the impact of HOV lanes on VMT and air pollution. J. Plan. Lit. 27 (4), 363-374.

SMA, 2013. Estudo de estratégias de gestão de mobilidade via teletrabalho e teleatividade no Estado de São Paulo. SMA - Secretaria de Meio Ambiente do Estado de São Paulo, São Paulo.

Small, K.A., 2012. Energy policies for passenger motor vehicles. Transp. Res. A 46 (2012), 874-889.

Small, K.A., Dender, K.V., 2007. Fuel efficiency and motor vehicle travel: the declining rebound effect. Energy J. 28 (1), 25-51.

SMVMA, 2005. Inventário de Emissões de Gases de Efeito Estufa do Município de São Paulo. São Paulo City Hall.

Sterman, J., 2000. Business Dynamics: Systems Thinking and Modeling for a Complex World. McGraw-Hill/Irwin.

STM, 2013. Monitoramento da Demanda 2009-2012. Secretaria de Transportes Metropolitanos do Estado de São Paulo, São Paulo.

Toledo, K., 2012. Programa de biodiesel não atingiu meta social. Agência FAPESP (May 07, 2013).

Turtelli, C., 2014. Municípios de SP sofrem com crise no setor da cana. Folha de S. Paulo (Jun. 22).

UNECE, 2011a. Development and implementation of a monitoring and assessment tool for $\mathrm{CO}_{2}$ emissions in inland transport to facilitate climate change mitigation. Project Documents for the 7th Tranche of the Development Account. Commission for Europe - Transport Division, United Nations Economic.

UNECE, 2011b. ForFITS user manual Access in Apr. 15, 2014, available at www.unece.org/ trans/theme_forfits.html.
UNECE, 2013. ForFITS pilot report Access in Apr. 15, 2014, available at www.unece.org/ trans/theme_forfits.html.

UNEP, 2011. Towards a Green Economy: Pathways to Sustainable Development and Poverty Eradication. United Nations Environment Programme.

Vieira, M.C., Lima, J.F., Braga, N.M., 2007. Setor Sucroalcooleiro Brasileiro: Evolução e Perspectivas. BNDES.

Wang, J., Lu, H., Peng, H., 2008. System dynamics model of urban transportation system and its application. J. Transp. Syst. Eng. Inf. Technol. 8 (3), 83-89.

World Bank, 2011. Brazil Low Carbon Case Study - Technical Synthesis Report - Transport. World Bank.

Esther Menezes is an economist, since 2010 working as specialist in public policy at São Paulo State Office for Planning and Management and at Metropolitan Agency of Campinas. She holds a Msc in Science and Technology Policy at the State University of Campinas and she is a PhD candidate in Development Economics at State University of Campinas. Her works focus on impact assessment of public policies, new technologies and urban environmental issues.

Alexandre Gori Maia is professor of economics at the State University of Campinas and coordinates the Center for Agricultural and Environmental Economics. He is $\mathrm{PhD}$ in $\mathrm{Ap}-$ plied Economics, Msc in Economic Development at State University of Campinas and made post-doctorate researches in Latin American Studies at University of Texas - Austin and in Geography at University of São Paulo. He works with quantitative methods applied to social economy and the environment, specifically with: economic demography, economic valuation of environmental resources; inequality and socioeconomic structure.

Cristiane Silva Carvalho is an Industrial Engineer with a Master degree in Social and Political Studies of Latin America from Universidad Alberto Hurtado (Chile) and is a PhD candidate in Engineering in Management and Optimization at UNESP. She has worked as consultant and specialist in sustainable development, climate change and urban planning of the Economic Commission for Latin America and the Caribbean (UN-ECLAC) for five years. 